\title{
Transcriptome profiling of granulosa cells from bovine ovarian follicles during atresia
}

\author{
Nicholas Hatzirodos ${ }^{1}$, Katja Hummitzsch ${ }^{1}$, Helen F Irving-Rodgers ${ }^{1,2}$, Margaret L Harland ${ }^{1}$, Stephanie E Morris ${ }^{1}$ \\ and Raymond J Rodgers ${ }^{1 *}$
}

\begin{abstract}
Background: The major function of the ovary is to produce oocytes for fertilisation. Oocytes mature in follicles surrounded by nurturing granulosa cells and all are enclosed by a basal lamina. During growth, granulosa cells replicate and a large fluid-filled cavity (the antrum) develops in the centre. Only follicles that have enlarged to over $10 \mathrm{~mm}$ can ovulate in cows. In mammals, the number of primordial follicles far exceeds the numbers that ever ovulate and atresia or regression of follicles is a mechanism to regulate the number of oocytes ovulated and to contribute to the timing of ovulation. To better understand the molecular basis of follicular atresia, we undertook transcriptome profiling of granulosa cells from healthy $(n=10)$ and atretic $(n=5)$ bovine follicles at early antral stages $(<5 \mathrm{~mm})$.

Results: Principal Component Analysis (PCA) and hierarchical classification of the signal intensity plots for the arrays showed primary clustering into two groups, healthy and atretic. These analyses and size-frequency plots of coefficients of variation of signal intensities revealed that the healthy follicles were more heterogeneous. Examining the differentiallyexpressed genes the most significantly affected functions in atretic follicles were cell death, organ development, tissue development and embryonic development. The overall processes influenced by transcription factor gene TP53 were predicted to be activated, whereas those of MYC were inhibited on the basis of known interactions with the genes in our dataset. The top ranked canonical pathway contained signalling molecules common to various inflammatory/fibrotic pathways such as the transforming growth factor- $\beta$ and tumour necrosis factor- $\alpha$ pathways. The two most significant networks also reflect this pattern of tissue remodelling/fibrosis gene expression. These networks also contain molecules which are present in the canonical pathways of hepatic fibrosis/hepatic stellate cell activation and transforming growth factor- $\beta$ signalling and were up regulated.
\end{abstract}

Conclusions: Small healthy antral follicles, which have a number of growth outcomes, exhibit greater variability in gene expression, particularly in genes associated with cell division and other growth-related functions. Atresia, on the other hand, not only involves cell death but clearly is an active process similar to wound healing.

Keywords: Ovary, Microarray analysis, Bovine, Granulosa cells, Atresia, Follicles

\section{Background}

The function of the ovary is to produce and release oocytes to be fertilised, leading to the production of offspring. Oocytes develop within ovarian follicles which in most mammals are formed during fetal life. These primordial follicles consist of an oocyte arrested in meiosis, and therefore not capable of mitosis. The oocyte is

\footnotetext{
* Correspondence: ray.rodgers@adelaide.edu.au

${ }^{1}$ Research Centre for Reproductive Health, Discipline of Obstetrics and Gynaecology, School of Paediatrics and Reproductive Health, Robinson Institute, University of Adelaide, Adelaide 5005SA, Australia

Full list of author information is available at the end of the article
}

surrounded by a single layer of inactive pregranulosa cells [1]. These primordial follicles comprise the 'ovarian reserve' from which a number of follicles are activated each day to commence growth and maturation. During this process of folliculogenesis, the oocyte enlarges substantially, pregranulosa cells differentiate into granulosa cells and replicate, and a large fluid-filled antrum develops in the middle of the follicle [2]. The growth of antral follicles is largely under the influence of FollicleStimulating Hormone (FSH) [3]. During follicle growth granulosa cells produce increasingly more of the hormone oestradiol. After the surge release of Luteinising

\section{Biomed Central}


Hormone ( $\mathrm{LH}$ ) from the anterior pituitary gland which results in ovulation of the oocyte, the remaining granulosa cells of the follicle wall transform into luteal cells of the corpus luteum and produce progesterone [4]. Hence both the numbers and maturation of granulosa cells in any given follicle are important and both processes are regulated by gonadotrophic hormones from the anterior pituitary.

In mammals, the number of primordial follicles far exceeds the numbers that ovulate over a lifetime. For example in humans, millions of primordial follicles are formed in the fetal gonad but only about 500 will be ovulated [5]. Since the numbers of follicles at menopause is practically nil [5], the vast majority of follicles undergo atresia and regress. The incidence of follicular atresia [6] is a normal process of ovarian function and its occurrence across species appears to have increased, with the evolution of viviparity in which a reduced number of female gametes are required when compared to mass-spawning species. Atresia in any species can regulate the number of oocytes ovulated and contribute to the timing of ovulation in a reproductive cycle.

The process of atresia in follicles large enough to have developed an antral cavity is characterised initially by death of the mural granulosa cells with the presence of pyknotic nuclei followed by loss of these layers into the antrum [7]. The entire follicle wall then begins to breakdown at the basal lamina and inflammatory cells migrate from the surrounding stromal theca layers, phagocytosing remnants of the granulosa cells and eventually the oocyte. Atresia leads eventually to death of all the granulosa cells within a follicle. The cell death processes can involve apoptosis, necrosis, autophagy and cornification, and any of the major cell types of the follicle can be involved, depending upon the stage of follicular development when atresia occurs [8]. Atresia also involves active cellular processes including macrophage infiltration, phagocytosis, migration of fibroblasts from the theca and the production of collagen. Interestingly, these are some of the processes also observed in wound healing $[9,10]$.

We hypothesise that apart from cell death, other signalling and pathways will be associated with the process of atresia. Therefore, to advance our knowledge of atresia we undertook transcriptome profiling of granulosa cells from small antral follicles before and during atresia. There have been several studies published, which investigate granulosa gene expression in developing bovine antral follicles by microarray [11-14]. Evans et al [11] studied granulosa from small follicles using self-generated arrays of approximately 1,300 genes. Other studies have focused on follicles at larger sizes, comparing follicles with differences in oestradiol production due to selectively accelerated development (dominance). Here we examined individual morphologically-classified healthy $(\mathrm{n}=10)$ and atretic $(n=5)$ follicles at the small antral stage of less than $5 \mathrm{~mm}$ in diameter, prior to size deviation due to dominant selection. The Bovine Affy arrays we used contain more than 11,000 annotated genes, thereby expanding the power to reveal networks and pathways involved in follicle regression. The healthy follicles were further classified into two phenotypes based upon the shape of the basallysituated granulosa cells, as either columnar or rounded [15]. These follicle types also differ in the quality of their oocytes when cultured in vitro [16]. The atretic follicles were of the type called antral atretic $[7,8]$. This is the classic type of atresia commonly observed across species in which the antrally-situated granulosa cells are the first to undergo cell death.

\section{Results and discussion}

In this study we have identified major differences in gene expression pathways and networks that develop in granulosa cells of small antral follicles during the process of atresia. To achieve this, granulosa cells from small healthy (3.1 \pm SEM $0.2 \mathrm{~mm}$ diameter; $\mathrm{n}=10)$ and atretic $(4.2 \pm 0.5 \mathrm{~mm} ; \mathrm{n}=5)$ follicles were selected for the microarray gene expression analysis. To ensure that the granulosa cells isolated were not contaminated with any thecal cells, no follicles with more than a $1 \%$ level of expression of CYP17A1 found in thecal samples were included. CYP17A1 is expressed exclusively in thecal cells [17]. We also validated that our microarray analyses could detect differentially-expressed genes here by immunohistochemistry and elsewhere [18] by real time reverse transcription polymerase chain reaction (real time RT-PCR). Table 1 shows the selected genes and their signal intensities and fold differences between healthy and atretic follicles. $C D H 1$, the gene for the cell-cell adhesion molecule E-cadherin, and NID2, the gene for nidogen 2, were both increased in atretic follicles. By immunohistochemistry, the levels of both E-cadherin (Figure 1A, B) and nidogen 2 (Figure $1 \mathrm{C}, \mathrm{D}$ ) were elevated in the membrana granulosa of atretic follicles. Collagen type I was also examined by immunohistochemistry on the basis that

Table 1 Expression of selected genes from the microarray analysis used for validation by immunohistochemistry

\begin{tabular}{|c|c|c|c|}
\hline \multirow{2}{*}{$\begin{array}{l}\text { Gene } \\
\text { symbol }\end{array}$} & \multicolumn{2}{|c|}{$\log _{2}$ mean signal intensity \pm SD +} & \multirow{2}{*}{$\begin{array}{c}\text { Fold increases } \\
\text { in atretic follicles } \neq\end{array}$} \\
\hline & $\begin{array}{l}\text { Healthy follicles } \\
\qquad(n=10)\end{array}$ & $\begin{array}{l}\text { Atretic follicles } \\
\qquad(n=5)\end{array}$ & \\
\hline $\mathrm{CDH1}$ & $6.5 \pm 0.7$ & $8.9 \pm 1.4$ & 4.3 \\
\hline COLIA1 & $7.9 \pm 0.3$ & $7.0 \pm 0.7$ & -1.5 \\
\hline COLIA2 & $6.6 \pm 0.2$ & $8.7 \pm 1.9$ & 5.3 \\
\hline NID2 & $5.0 \pm 0.6$ & $9.2 \pm 1.4$ & 18.4 \\
\hline
\end{tabular}

† SD = standard deviation.

₹ fold change calculated on non-log transformed data. 

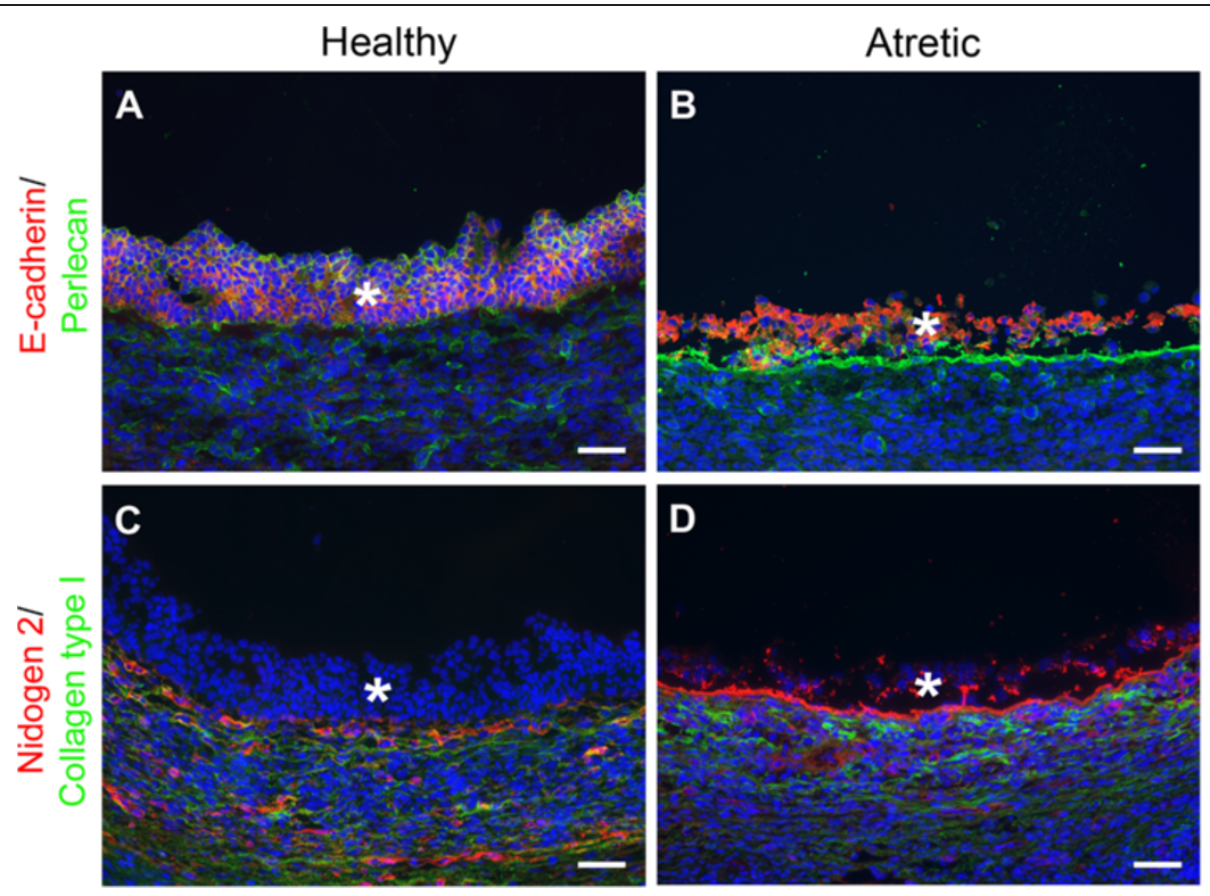

Figure 1 Localisation of E-cadherin, perlecan, nidogen 2 and collagen type I in small healthy and atretic follicles. (A, B) E-cadherin (red) is restricted to the membrana granulosa and is strongly expressed in atretic follicles. Perlecan (green) marks the follicular and sub-endothelial basal lamina and is expressed in the cytoplasm of granulosa cells of healthy and atretic follicles. (C, D) Nidogen-2 (red) is localised to the basal lamina of both follicle types, but is only expressed in the granulosa layer of small atretic follicles. Collagen type I (green) is not localised to the granulosa cells. It is restricted to the thecal and medullar stroma. The star indicates the granulosa layer. Bar $=50 \mu \mathrm{m}$.

COL1A2 was elevated in atretic follicles. However, no collagen type 1 was detected in the membrana granulosa of healthy or atretic follicles but it was identified in the thecal layers at higher levels in atretic follicles. Collagen type I contains both $\alpha 1$ and $\alpha 2$ subunits and whilst COL1A2 was elevated COL1A1 was not. Thus expression of collagen type I could not be validated, but both $C D H 1$ and NID2 were.

\section{Statistical analysis of differentially-expressed genes}

Small healthy follicles were classified as either columnar $(n=5)$ or rounded $(n=5)$ on the basis of the shape of the basally-situated granulosa cells $[15,16]$ as described in the Methods. PCA for the first three components (Figure 2) and hierarchical clustering (Figure 3 ) for the total number of probe sets $(n=24,182)$ of all arrays in this study were conducted. Neither of these unsupervised analytical methods separated the small healthy follicle arrays into the rounded and columnar groups, and in fact no genes were shown to be more than 2-fold differentially expressed between the two subgroups with a BenjaminiHochberg False Discovery Rate (FDR) of $P<0.05$ by ANOVA. Therefore, the small healthy follicle arrays were treated as a single group for further analyses $(n=10)$ and compared with the small atretic follicle group.

Before statistical analysis, PCA for all arrays revealed that the first principal component which accounted for
$51 \%$ of the variation in the data, could separate the atretic and healthy follicle groups (Figure 2). Hierarchical classification of the signal intensity plot for these arrays similarly also showed primary clustering of the arrays into these two groups (Figure 3). The numbers of

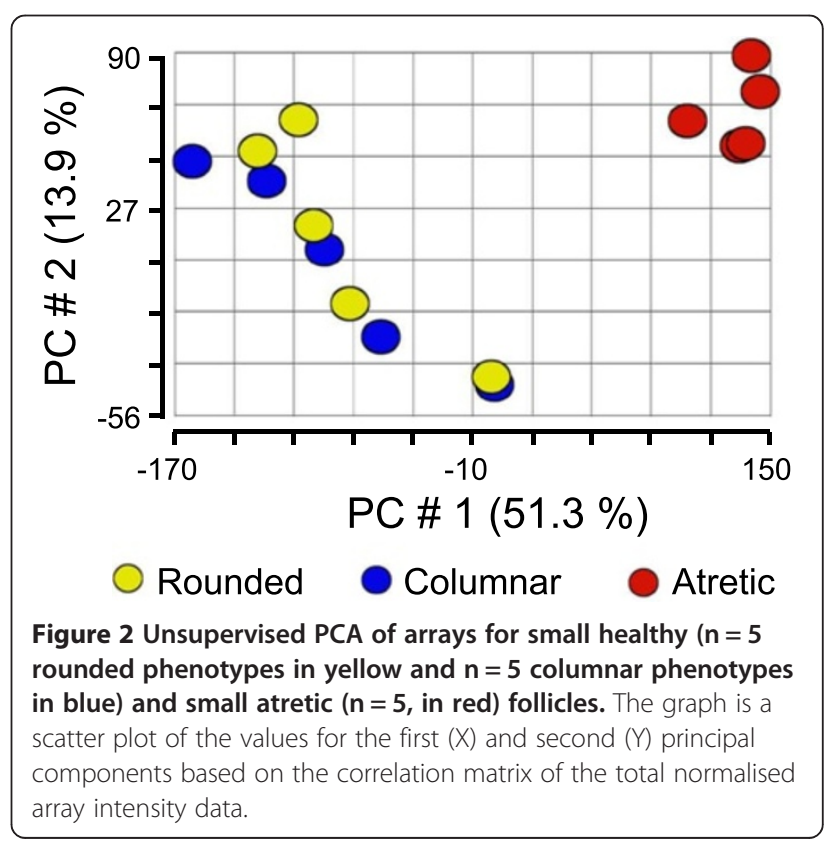




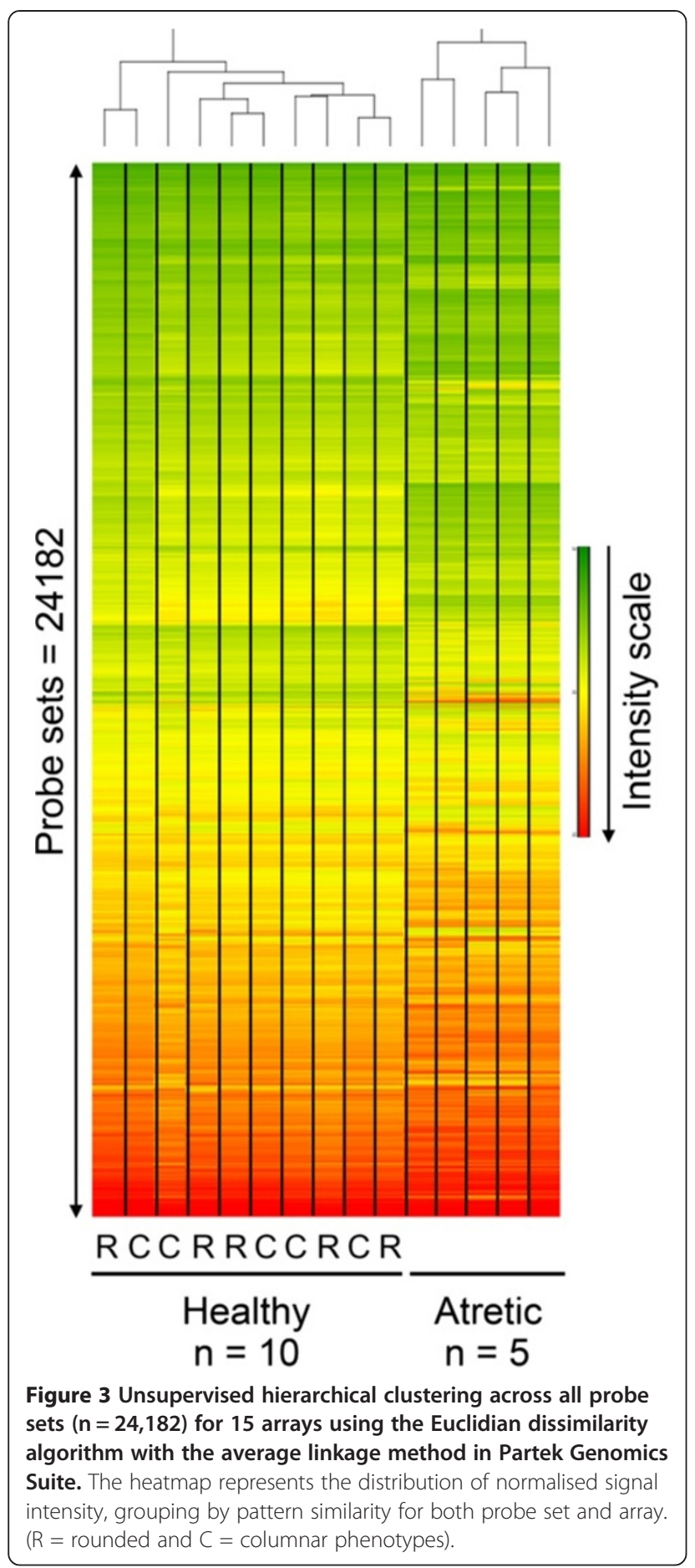

genes enriched 2-, 3-, and -4 fold by ANOVA in either healthy or atretic follicles are shown in Table 2. Follicular atresia was characterized by considerable change in the transcriptional processes of the granulosa cells as expected with over $22 \%$ of the total genes on the array being affected at least 2 fold or more (5,439 from 24,182). Four hundred and forty probesets were up regulated and 265 were down regulated more than 4 fold in atretic
Table 2 Number of probe sets differentially expressed in atretic follicles with respect to healthy follicles

\begin{tabular}{lllll}
\hline $\begin{array}{l}\text { False discovery } \\
\text { rate }\end{array}$ & $\begin{array}{l}\text { Fold } \\
\text { change }\end{array}$ & $\begin{array}{l}\text { Up } \\
\text { regulated }\end{array}$ & $\begin{array}{l}\text { Down } \\
\text { regulated }\end{array}$ & Total \\
\hline$P<0.05$ & $>2$ & 2573 & 2866 & 5439 \\
& $>3$ & 824 & 771 & 1595 \\
& $>4$ & 440 & 265 & 705 \\
\hline$>0.005$ & $>2$ & 2397 & 2736 & 5133 \\
& $>3$ & 801 & 732 & 1533 \\
& $>4$ & 433 & 257 & 690 \\
\hline
\end{tabular}

Determined by ANOVA and the step-up Benjamini Hochberg False Discovery Rate method for multiple corrections using Partek Genomics Suite Software.

follicles relative to small healthy follicles. Using thresholds of 3- and 4-fold differential-expression levels with $P<0.05$ and $<0.005$ respectively, then 1,595 and 690 differentially-expressed probe sets were identified, respectively (Table 2). The larger dataset (1,595 probe sets) was tabulated with gene and fold change details added as Table 3 (up regulated in atretic) and Table 4 (down regulated) and in Additional file 1: Table S1.

\section{Variability of gene expression between follicles}

The PCA indicated that the healthy follicles were a more heterogeneous group than the atretic follicles and we examined this further. In other studies examination of the variably expressed genes has recently been used as a tool to identify differences in the pathways of different neurological diseases [19], therefore we applied a similar approach to our data. The coefficients of variation (SD/ Mean $\times 100)$ for the healthy and the atretic follicles of each probe set were calculated and the size-frequency distribution plot for healthy and atretic follicles is shown in Figure 4. The healthy follicles (Figure 4A) show increasing gene variation with increasing fold difference for the subset of genes which are differentially regulated between healthy and atretic follicles, which is not seen in the atretic follicle group (Figure 4B). We investigated this variation further and identified the most highly variable genes in small healthy follicles. A group of 682 of the most variable probe sets in small healthy follicles, which had a coefficient of variation value of $>46.8 \%$, was assembled and analysed by Ingenuity Pathway Analysis (IPA) and Gene Ontology (GO) enrichment analysis (Tables 5 and 6). Cell cycle regulation is the most common function associated with the highly variable gene dataset. Thirteen genes were associated with GO terms for this function and cyclin genes such as CCNB1, $C C N B 2$ and $C D K 1$ were represented in both analyses and in the top canonical pathways. The enrichment analysis produced a number of additional functionallyrelated gene groups associated with variable expression. These categories included; regulation of vascularity, extracellular matrix, energy metabolism, inflammation, 
Table 3 Genes which were up regulated in small atretic follicles with respect to healthy follicles ${ }^{\dagger}$

\begin{tabular}{|c|c|c|c|c|c|}
\hline Gene symbol & Fold change & Gene symbol & Fold change & Gene symbol & Fold change \\
\hline \multicolumn{6}{|c|}{ Cell Cycle and DNA replication } \\
\hline CDKN1C & 40.2 & RGCC & 5.1 & IFITM3 & 3.3 \\
\hline MICALI & 8.9 & TOP1 & 5.1 & DYNLT3 & 3.1 \\
\hline CDC37L1 & 5.9 & RAD52 & 3.5 & $B A Z 1 A$ & 3.0 \\
\hline TOPORS & 5.7 & KLC1 & 3.4 & & \\
\hline \multicolumn{6}{|c|}{ Cell Death } \\
\hline TNFRSF12A & 10.4 & *PHLDA1 & 4.7 & TNFRSF25 & 3.4 \\
\hline CFLAR & 6.0 & PDCD4 & 3.9 & TNFRSF1A & 3.2 \\
\hline TNFRSF6B & 5.9 & FAIM & 3.8 & PDCD10 & 3.1 \\
\hline \multicolumn{6}{|c|}{ Cell Morphology } \\
\hline MAPILC3C & 16.7 & APBBIIP & 4.6 & SNTB2 & 4.0 \\
\hline CAPG & 11.1 & MAP2 & 4.5 & MTMR3 & 3.8 \\
\hline TAGLN & 10.8 & CNN1 & 4.4 & LMNA & 3.5 \\
\hline DBNDD2 & 9.2 & AIF1L & 4.4 & ABLIMI & 3.5 \\
\hline$N D R G 1$ & 9.0 & $V C L$ & 4.3 & FHOD3 & 3.4 \\
\hline SYNE1 & 7.6 & WASL & 4.3 & MARCKSLI & 3.2 \\
\hline CLDN5 & 6.3 & $\mathrm{CDH} 1$ & 4.3 & MAP9 & 3.2 \\
\hline SVIL & 6.1 & ACTA2 & 4.3 & MICAL2 & 3.1 \\
\hline MICALL2 & 6.1 & TAGLN2 & 4.3 & ELMO1 & 3.1 \\
\hline FILIPIL & 5.6 & FSCN1 & 4.2 & ELMO2 & 3.1 \\
\hline$A R P C 1 B$ & 5.5 & FNBP1L & 4.1 & ${ }^{*} A R F 5$ & 3.1 \\
\hline FERMT2 & 5.4 & TLN1 & 4.1 & TPGS1 & 3.0 \\
\hline GSN & 5.3 & ACTN1 & 4.1 & B9D2 & 3.0 \\
\hline TUBB6 & 5.1 & DSTN & 4.0 & FBLIMI & 3.0 \\
\hline CAVI & 4.6 & RILPL2 & 4.0 & & \\
\hline \multicolumn{6}{|c|}{ Cytokines, Hormones and Receptors } \\
\hline PDGFRA & 26.5 & IGF2R & 6.2 & CD302 & 3.7 \\
\hline SCG2 & 24.4 & ELTD1 & 6.1 & $J A G 1$ & 3.6 \\
\hline CTGF & 23.4 & TSPO & 5.7 & ILIORA & 3.6 \\
\hline DKK3 & 17.4 & IGFBP6 & 5.1 & PTPRK & 3.6 \\
\hline$X C L 1$ & 16.7 & IGF2 & 5.0 & PLXND1 & 3.6 \\
\hline SPP1 & 14.1 & TGFBR2 & 5.0 & CMTM3 & 3.5 \\
\hline OLR1 & 11.7 & MIA3 & 4.6 & ILI7RA & 3.5 \\
\hline MDK & 9.9 & $|F| 30$ & 4.5 & NR4A2 & 3.5 \\
\hline IL18 & 8.9 & IGFBP5 & 4.3 & ANGPTL4 & 3.4 \\
\hline PRICKLEI & 8.2 & EFNA4 & 4.2 & EFNA5 & 3.3 \\
\hline$B A M B I$ & 7.6 & $N R 2 F 1$ & 4.1 & GPRC5B & 3.3 \\
\hline NDP & 7.6 & $A D M$ & 3.9 & GPR155 & 3.3 \\
\hline GNG2 & 7.3 & PLXNB2 & 3.8 & ACVR1 & 3.1 \\
\hline PLAUR & 6.7 & ${ }^{*} P \vee R L 2$ & 3.8 & SCG5 & 3.1 \\
\hline BMP2 & 6.6 & & & & \\
\hline \multicolumn{6}{|c|}{ Directional Cell Growth } \\
\hline SLITRK2 & 4.3 & ROCK2 & 3.8 & ROCK1 & 3.3 \\
\hline
\end{tabular}


Table 3 Genes which were up regulated in small atretic follicles with respect to healthy follicles ${ }^{\dagger}$ (Continued)

\begin{tabular}{|c|c|c|c|c|c|}
\hline \multicolumn{6}{|c|}{ Extracellular Matrix and Synthesis } \\
\hline *SPOCK2 & 23.8 & TNFAIP6 & 7.1 & COL18A1 & 4.0 \\
\hline *NID2 & 18.5 & $L O X L 4$ & 6.5 & ${ }^{*}$ FN1 & 3.9 \\
\hline *LEPREL 1 & 12.8 & LUM & 6.1 & FBN1 & 3.8 \\
\hline$\angle A M B 1$ & 12.0 & COL3A1 & 5.5 & COL4A5 & 3.5 \\
\hline$D C N$ & 11.1 & COL1A2 & 5.3 & SPON2 & 3.5 \\
\hline MGP & 9.5 & PCOLCE2 & 4.6 & SDC4 & 3.4 \\
\hline SDC2 & 9.0 & COL4A1 & 4.5 & COL12A1 & 3.4 \\
\hline FBLN2 & 8.7 & $A G R N$ & 4.1 & COL6A1 & 3.2 \\
\hline COL5A2 & 8.3 & & & & \\
\hline \multicolumn{6}{|c|}{ Intercellular and Cell to Matrix Adhesion } \\
\hline KRT18 & 62.4 & CLDN1 & 10.2 & MAG/3 & 4.6 \\
\hline KRT8 & 53.2 & CD9 & 7.1 & AMIGO2 & 4.5 \\
\hline PTX3 & 24.1 & $\mathrm{PCDH7}$ & 7.0 & ANTXR2 & 3.7 \\
\hline THBS2 & 23.9 & FLNB & 6.6 & SPARC & 3.6 \\
\hline LGALS3 & 22.9 & MAG/1 & 6.0 & CADM1 & 3.3 \\
\hline${ }^{*} \mathrm{CD} 24$ & 17.1 & VMP1 & 5.3 & JAM3 & 3.2 \\
\hline CYR61 & 14.1 & CLDN11 & 4.9 & CCDC80 & 3.0 \\
\hline CALD1 & 11.6 & & & & \\
\hline \multicolumn{6}{|c|}{ Ion Transport } \\
\hline KCNMB4 & 5.7 & CACNB3 & 4.0 & KCTD10 & 3.8 \\
\hline GPM6A & 4.8 & CLCA4 & 3.9 & SEPP1 & 3.7 \\
\hline CLIC4 & 4.5 & SCN5A & 3.9 & KCNJ2 & 3.7 \\
\hline \multicolumn{6}{|c|}{ Protein Trafficking } \\
\hline ANXA1 & 10.9 & SCG3 & 4.0 & PLEKHB2 & 3.6 \\
\hline GABARAPL 1 & 6.2 & CHMP5 & 3.7 & SCAP & 3.4 \\
\hline GIT2 & 4.4 & $M V P$ & 3.7 & PLEKHG2 & 3.3 \\
\hline SH3RF1 & 4.0 & & & & \\
\hline \multicolumn{6}{|c|}{ Proteolysis or Inhibition } \\
\hline TIMP1 & 68.9 & CAST & 6.7 & CTSZ & 3.5 \\
\hline PLAT & 26.5 & ADAMTS1 & 6.1 & $F B X 032$ & 3.3 \\
\hline SERPINEI & 19.3 & CIS & 5.9 & TIMP2 & 3.3 \\
\hline PRSS23 & 10.9 & CTSH & 4.7 & CTSK & 3.2 \\
\hline CSTB & 9.3 & MMP11 & 4.4 & CTSB & 3.2 \\
\hline RELN & 7.7 & CTSS & 4.4 & KLHL36 & 3.2 \\
\hline MMP23B & 7.7 & CFD & 3.8 & SERPINB2 & 3.1 \\
\hline SERPINB8 & 7.4 & PSMB1 & 3.5 & $L Y Z$ & 3.0 \\
\hline \multicolumn{6}{|c|}{ RNA Processing } \\
\hline PRPF38B & 7.1 & RBM25 & 3.9 & SNRNP200 & 3.2 \\
\hline RBMS2 & 6.3 & $D D \times 5$ & 3.7 & HNRNPH3 & 3.2 \\
\hline RBM24 & 4.6 & SYNCRIP & 3.6 & CPEB4 & 3.2 \\
\hline RBM17 & 4.5 & DDX42 & 3.6 & EBNA1BP2 & 3.1 \\
\hline TDRD7 & 4.3 & INTS7 & 3.3 & GEMIN8 & 3.1 \\
\hline REXO2 & 4.0 & CWC22 & 3.2 & & \\
\hline
\end{tabular}


Table 3 Genes which were up regulated in small atretic follicles with respect to healthy follicles ${ }^{\dagger}$ (Continued)

\begin{tabular}{|c|c|c|c|c|c|}
\hline \multicolumn{6}{|c|}{ Transcription Regulation } \\
\hline ANKRD1 & 48.9 & TAXIBP3 & 4.8 & LEF1 & 3.4 \\
\hline FOSL2 & 11.7 & ${ }^{*} M L L 3$ & 4.7 & TGIF1 & 3.4 \\
\hline EGR1 & 11.3 & MTPN & 4.6 & MPHOSPH8 & 3.4 \\
\hline ATF3 & 9.7 & EPAS1 & 4.6 & MORF4L2 & 3.3 \\
\hline$B C L 6$ & 8.6 & FOXP1 & 4.5 & MAFK & 3.3 \\
\hline ATRX & 8.4 & ING4 & 4.4 & CSRNP1 & 3.3 \\
\hline ID1 & 7.4 & GTF2F2 & 4.4 & LARP7 & 3.3 \\
\hline USF1 & 6.8 & SMAD3 & 4.3 & GTF2E2 & 3.3 \\
\hline KLF6 & 6.5 & STAT3 & 4.3 & GTF2H4 & 3.3 \\
\hline RBFOX2 & 6.5 & SERTADI & 4.3 & BASP1 & 3.3 \\
\hline JUN & 6.4 & HHEX & 4.2 & LEO1 & 3.3 \\
\hline CEBPD & 6.0 & ZNF398 & 4.2 & TCF3 & 3.3 \\
\hline ID3 & 5.8 & HMBOX1 & 4.0 & ZMIZ2 & 3.2 \\
\hline *TCF7L2 & 5.8 & PDLIM1 & 3.9 & NFKBIA & 3.2 \\
\hline HDAC7 & 5.8 & ZFP36L1 & 3.9 & $\mathrm{ZC} 3 \mathrm{H}_{8}$ & 3.2 \\
\hline NMl & 5.7 & $J U N B$ & 3.9 & OSTF1 & 3.2 \\
\hline SNAI2 & 5.7 & E4F1 & 3.9 & CIR1 & 3.2 \\
\hline ZNF292 & 5.7 & ZNF281 & 3.8 & ZNHIT3 & 3.1 \\
\hline LITAF & 5.6 & FOS & 3.7 & GPS2 & 3.1 \\
\hline CITED2 & 5.6 & FHL2 & 3.7 & CSDC2 & 3.1 \\
\hline CTR9 & 5.5 & CYLD & 3.7 & KHDRBS1 & 3.0 \\
\hline${ }^{*} C E B P D$ & 5.4 & TRANK1 & 3.6 & ILF3 & 3.0 \\
\hline KANK2 & 5.1 & FOXO1 & 3.6 & ANKRD10 & 3.0 \\
\hline NFIL3 & 5.0 & ${ }^{*} C P E B 2$ & 3.6 & & \\
\hline JARID2 & 4.9 & SCAND1 & 3.5 & & \\
\hline MXI1 & 4.9 & HDAC5 & 3.5 & & \\
\hline \multicolumn{6}{|c|}{ Translation Regulation } \\
\hline MRPS28 & 3.6 & EIF4G3 & 3.2 & EIF2AK4 & 3.2 \\
\hline EIF2AK4 & 3.5 & & & & \\
\hline \multicolumn{6}{|c|}{ Transport } \\
\hline$A P O D$ & 37.5 & SLC25A29 & 4.2 & RBP1 & 3.4 \\
\hline STAR & 22.5 & STAU1 & 4.1 & TCN2 & 3.4 \\
\hline SLC17A5 & 9.0 & VPS13B & 4.1 & SLC25A17 & 3.4 \\
\hline FABP5 & 8.9 & STEAP1 & 4.0 & CYTH3 & 3.4 \\
\hline$A 2 M$ & 8.1 & RABEP1 & 3.9 & SYT11 & 3.2 \\
\hline NNAT & 7.8 & ${ }^{*} A B C B 1$ & 3.8 & FABP4 & 3.1 \\
\hline SLC4OA1 & 7.2 & CRABP2 & 3.7 & AP1S2 & 3.1 \\
\hline VAT1 & 6.8 & STARD3NL & 3.7 & NPC2 & 3.0 \\
\hline SLC39A8 & 5.2 & ANKH & 3.6 & SNX9 & 3.0 \\
\hline \multicolumn{6}{|c|}{ Other Enzymes } \\
\hline *VNN1 & 15.1 & PNMT & 4.1 & $R A B 31$ & 3.2 \\
\hline${ }^{*} P D K 4$ & 9.7 & HSP9OAA1 & 4.0 & PTPRN2 & 3.2 \\
\hline GFPT2 & 7.8 & $R A P 2 C$ & 4.0 & RIOK2 & 3.2 \\
\hline
\end{tabular}


Table 3 Genes which were up regulated in small atretic follicles with respect to healthy follicles ${ }^{\dagger}$ (Continued)

\begin{tabular}{|c|c|c|c|c|c|}
\hline QSOX1 & 5.9 & SETD7 & 4.0 & RNF20 & 3.2 \\
\hline $\mathrm{DDAH2}$ & 5.5 & CHST2 & 4.0 & LHFPL2 & 3.2 \\
\hline GLRX & 5.4 & SMS & 3.8 & PTPN21 & 3.2 \\
\hline PLSCR4 & 5.4 & NT5E & 3.8 & $R A B 7 A$ & 3.1 \\
\hline ENPP5 & 4.9 & MARCKS & 3.7 & DDAH1 & 3.1 \\
\hline PYGL & 4.9 & GDPD1 & 3.6 & PPIE & 3.1 \\
\hline CA2 & 4.8 & DUSP7 & 3.6 & ARF5 & 3.1 \\
\hline RPIA & 4.7 & EGLN1 & 3.5 & RBKS & 3.1 \\
\hline PELI1 & 4.7 & ZNRF1 & 3.4 & UST & 3.1 \\
\hline MYCBP2 & 4.6 & NAGK & 3.4 & ENO2 & 3.1 \\
\hline CPT1A & 4.5 & MGST2 & 3.4 & RNF8 & 3.1 \\
\hline GEM & 4.4 & B4GALT5 & 3.4 & PLCL2 & 3.0 \\
\hline PIGT & 4.3 & $R A B 22 A$ & 3.3 & DPH5 & 3.0 \\
\hline DUSP1 & 4.3 & $A L D H 1 A 1$ & 3.3 & IP6K2 & 3.0 \\
\hline PXDN & 4.2 & & & & \\
\hline \multicolumn{6}{|c|}{ Other Signalling } \\
\hline${ }^{*} R N D 3$ & 35.7 & EFHD2 & 5.8 & SHISA2 & 3.9 \\
\hline${ }^{*} D C L K 1$ & 19.5 & $J A K 1$ & 5.7 & RALA & 3.9 \\
\hline GAL & 10.6 & VAV2 & 5.6 & CSNK2A1 & 3.7 \\
\hline POSTN & 9.9 & INSIG2 & 5.4 & BMPER & 3.7 \\
\hline ARHGEF11 & 9.9 & WDR44 & 5.0 & ARHGAP32 & 3.5 \\
\hline TP53INP1 & 8.9 & STK17A & 5.0 & S100A11 & 3.3 \\
\hline LMTK2 & 8.1 & PTPN5 & 4.6 & UACA & 3.2 \\
\hline SH3BP5 & 7.5 & WHSC1L1 & 4.5 & ERBB2 & 3.2 \\
\hline GIMAP8 & 7.5 & $|R A K| B P \mid$ & 4.4 & FYN & 3.2 \\
\hline SH3KBP1 & 7.4 & CFH & 4.4 & CORO1A & 3.2 \\
\hline ARHGEF3 & 7.1 & IFITM1 & 4.3 & $B C A R 1$ & 3.1 \\
\hline RSPO3 & 7.1 & PIK3CA & 4.3 & DOCK5 & 3.1 \\
\hline CD200 & 7.0 & $D A B 2$ & 4.3 & PIK3CD & 3.1 \\
\hline PLIN2 & 6.6 & CSNK1G2 & 4.2 & STK38L & 3.1 \\
\hline PKIB & 6.5 & MERTK & 4.1 & MAP2K3 & 3.1 \\
\hline FBXO33 & 6.2 & RASA2 & 4.1 & TYRO3 & 3.1 \\
\hline CD55 & 6.2 & PIM1 & 4.0 & CARD10 & 3.1 \\
\hline ERRFI1 & 6.1 & & & & \\
\hline CD99 & 6.0 & & & & \\
\hline DAPP1 & 5.8 & & & & \\
\hline \multicolumn{6}{|c|}{ Other } \\
\hline C8orf4 & 37.2 & RCN2 & 4.4 & $C B L B$ & 3.6 \\
\hline SATL1 & 15.2 & KIAA1598 & 4.4 & ASCC2 & 3.5 \\
\hline WDFY4 & 11.1 & FAM126B & 4.4 & FAM32A & 3.5 \\
\hline$P L X D C 2$ & 9.1 & ZNF317 & 4.2 & OCIAD2 & 3.5 \\
\hline LUC7L3 & 8.9 & Clorf35 & 4.2 & SAFB2 & 3.5 \\
\hline ZNF462 & 7.5 & RASAL2 & 4.2 & ALKBH4 & 3.4 \\
\hline NTN4 & 7.3 & AKAP8L & 4.1 & TSC22D3 & 3.4 \\
\hline
\end{tabular}


Table 3 Genes which were up regulated in small atretic follicles with respect to healthy follicles ${ }^{\dagger}$ (Continued)

\begin{tabular}{|c|c|c|c|c|c|}
\hline KIAA0408 & 7.2 & DENND3 & 4.1 & $I R G Q$ & 3.4 \\
\hline$R S R C 2$ & 7.1 & CIQTNF6 & 4.1 & AUTS2 & 3.4 \\
\hline C10orfio & 7.0 & CCDC85B & 4.1 & GATSL2 & 3.4 \\
\hline PHF3 & 6.4 & ARHGEF2 & 4.0 & COMMD4 & 3.4 \\
\hline SDE2 & 6.3 & MAP1B & 4.0 & MLLT11 & 3.3 \\
\hline BTBD3 & 6.1 & C3orf19 & 4.0 & ZFYVE1 & 3.3 \\
\hline TMEM14A & 5.9 & CUL9 & 4.0 & PPFIBP1 & 3.3 \\
\hline ODF2L & 5.8 & MAP7D1 & 3.9 & FAM129B & 3.3 \\
\hline MXRA8 & 5.8 & MTA3 & 3.9 & FLRT2 & 3.3 \\
\hline GLIPR2 & 5.6 & LIMCH1 & 3.9 & PRRC2C & 3.2 \\
\hline NDRG4 & 5.6 & KLHL24 & 3.9 & GPN3 & 3.2 \\
\hline TMEM176A & 5.4 & CXorf26 & 3.9 & MESDC1 & 3.2 \\
\hline MXRA5 & 5.3 & SHF & 3.9 & $A R M C X 3$ & 3.2 \\
\hline CRYAB & 5.1 & YPEL5 & 3.9 & SNN & 3.2 \\
\hline C7orf41 & 4.9 & PQLC3 & 3.9 & KIAA0922 & 3.2 \\
\hline ZNF608 & 4.9 & TMTC2 & 3.9 & TCP11L2 & 3.2 \\
\hline KLHL28 & 4.9 & HECA & 3.8 & ANKRD11 & 3.2 \\
\hline PLEKHO1 & 4.8 & C9orf3 & 3.8 & C1orf212 & 3.1 \\
\hline TACC2 & 4.8 & $L R C H 1$ & 3.8 & TMEMI76B & 3.1 \\
\hline GOLPH3L & 4.8 & DPH3 & 3.7 & SYAP1 & 3.1 \\
\hline ERRFI1 & 4.7 & CD83 & 3.7 & METRNL & 3.1 \\
\hline SRP14 & 4.7 & CTTNBP2NL & 3.7 & FAM160A2 & 3.1 \\
\hline ZDHHC23 & 4.7 & TES & 3.7 & MEF2BNB & 3.1 \\
\hline EML1 & 4.7 & GLTSCR2 & 3.7 & C5orf30 & 3.1 \\
\hline ANXA2 & 4.7 & CLU & 3.6 & ATG14 & 3.1 \\
\hline ZNF521 & 4.6 & LHFP & 3.6 & BOD1L1 & 3.1 \\
\hline PDLIM4 & 4.6 & $P K I G$ & 3.6 & $D E F B 4 A$ & 3.0 \\
\hline KIAA0232 & 4.4 & LSG1 & 3.6 & C17orf101 & 3.0 \\
\hline C12orf75 & 4.4 & & & & \\
\hline
\end{tabular}

Differentially regulated genes ( $>3$ fold, $P<0.05$ ) were annotated based on the Entrez Gene database. Genes are listed in descending order of fold change within each functional category.

† Benjamini-Hochberg post-hoc test for multiple corrections following one way ANOVA.

* Indicates genes determined from the Partek analysis based on the Affymetrix annotations which were not assigned identities by IPA.

cell migration and MAPK activity. Interestingly, there were 17 extracellular matrix genes found to be highly variable across our healthy follicle arrays, and several of them code for a number of collagen types $(1 \alpha 1,1 \alpha 2$, $3 \alpha 1,4 \alpha 3,4 \alpha 4$ and 18). Energy metabolism was identified as an important process with an association of 13 genes from this variable group, particularly glucose metabolism via ISR2, IGFBP2, PDK4 and ASPSCR1. Molecules known to promote angiogenesis in the ovary such as VEGF and angiopoietin, and an inhibitor thrombospondin, were also associated with our variable dataset.

The large variability of gene expression across healthy follicles is probably not unexpected since small growing follicles have a number of possible growth trajectories: 1. continued growth to become a dominant follicle, with the likelihood of a) ovulation or b) atresia, 2. continued growth as a subordinate follicle with atresia as the ultimate fate or 3. atresia at an earlier stage. Whether this variability reflects early commitment or predisposition of follicles to one of the three outcomes, or whether it reflects flexibility without a predetermined outcome is not clear at this stage. However, our identification of the pathways and genes involved is an important first step towards understanding the underlying mechanisms responsible for the growth and atresia of follicles.

\section{Pathway, network and upstream regulator analyses of} healthy versus atretic follicles

A set of 690 probe sets, which were more than 4-fold differentially regulated in signal intensity between atretic 
Table 4 Genes which were down regulated in small atretic follicles with respect to healthy folliclest

\begin{tabular}{|c|c|c|c|c|c|}
\hline Gene symbol & Fold change & Gene symbol & Fold change & Gene symbol & Fold change \\
\hline \multicolumn{6}{|c|}{ Cell Cycle } \\
\hline HAUS4 & 9.7 & CASC5 & 4.1 & FAM83D & 3.4 \\
\hline KIFC1 & 7.2 & *PTTG1 & 4.0 & CDCA2 & 3.3 \\
\hline TOP2A & 6.3 & $B \cup B 1$ & 3.9 & KIF23 & 3.3 \\
\hline HJURP & 5.6 & SKA3 & 3.9 & CENPF & 3.3 \\
\hline CDCA8 & 4.6 & TPX2 & 3.8 & MCM10 & 3.3 \\
\hline$M D C 1$ & 4.5 & SGOL1 & 3.8 & CDCA3 & 3.3 \\
\hline RAD51AP1 & 4.5 & CDC20 & 3.8 & OIP5 & 3.2 \\
\hline CENPE & 4.5 & GINS3 & 3.7 & ASPM & 3.2 \\
\hline ANAPC5 & 4.4 & $A S F 1 B$ & 3.7 & $\mathrm{NCAPH}$ & 3.2 \\
\hline NUSAP1 & 4.3 & CDC6 & 3.7 & MAD2L1 & 3.1 \\
\hline MYO1D & 4.3 & ERCC6L & 3.6 & CKAP2 & 3.1 \\
\hline$K L C 2$ & 4.3 & CCNB1 & 3.6 & ${ }^{*}$ CENPA & 3.1 \\
\hline BUB1B & 4.2 & PRCC & 3.5 & $A \cup R K B$ & 3.0 \\
\hline CNNM2 & 4.2 & CENPN & 3.5 & & \\
\hline \multicolumn{6}{|c|}{ Cell Death } \\
\hline TRIB2 & 6.5 & RIPK3 & 4.8 & & \\
\hline \multicolumn{6}{|c|}{ Cell Morphology } \\
\hline CKAP2L & 4.7 & SRGN & 4.0 & MAPT & 3.3 \\
\hline PLP1 & 4.6 & $H M M R$ & 3.8 & $P R C 1$ & 3.3 \\
\hline JAKMIP1 & 4.6 & RSPHO & 3.7 & TNNC1 & 3.2 \\
\hline TMEM138 & 4.5 & SYNPO & 3.6 & PHACTR1 & 3.1 \\
\hline ECT2 & 4.2 & LEMD2 & 3.5 & MYO5C & 3.0 \\
\hline TMEM216 & 4.0 & $\mathrm{CDH} 26$ & 3.5 & & \\
\hline \multicolumn{6}{|c|}{ Cytokines, Hormones and Receptors } \\
\hline FGFR2 & 8.4 & INHA & 3.8 & CCR3 & 3.2 \\
\hline F2RL2 & 5.9 & ADRA1A & 3.7 & CHRM4 & 3.2 \\
\hline VEGFA & 5.8 & IL7 & 3.6 & P2RY10 & 3.2 \\
\hline RHO & 5.8 & CD5 & 3.6 & NR5A1 & 3.2 \\
\hline IL17RE & 5.5 & GPR128 & 3.6 & OPN1LW & 3.2 \\
\hline LTA & 4.8 & GPR61 & 3.6 & $A H R$ & 3.2 \\
\hline IL18R1 & 4.6 & GPR77 & 3.5 & IL2ORA & 3.2 \\
\hline FSHR & 4.4 & FGF10 & 3.4 & HTR1D & 3.2 \\
\hline HTR2A & 4.4 & CCL11 & 3.4 & FGFBP1 & 3.1 \\
\hline$A M H$ & 4.2 & $O P C M L$ & 3.4 & $T S H B$ & 3.1 \\
\hline GPRC5A & 4.2 & CCL25 & 3.4 & ASGR1 & 3.1 \\
\hline OPRM1 & 4.2 & CCL28 & 3.4 & HEG1 & 3.1 \\
\hline INHBA & 4.2 & $F I G F$ & 3.4 & $I L 1 A$ & 3.1 \\
\hline NTRK3 & 4.1 & CD72 & 3.3 & $|G F|$ & 3.1 \\
\hline FST & 4.0 & $A B P 1$ & 3.3 & CASR & 3.0 \\
\hline FSHB & 4.0 & EDNRA & 3.3 & GMFG & 3.0 \\
\hline IL21 & 4.0 & ITGB3 & 3.2 & HTR4 & 3.0 \\
\hline BMP15 & 3.8 & NGFR & 3.2 & & \\
\hline
\end{tabular}


Table 4 Genes which were down regulated in small atretic follicles with respect to healthy folliclest (Continued)

\begin{tabular}{|c|c|c|c|c|c|}
\hline \multicolumn{6}{|c|}{ Directional Cell Growth } \\
\hline FAT1 & 3.6 & & & & \\
\hline \multicolumn{6}{|c|}{ Extracellular Matrix and Synthesis } \\
\hline LAMC2 & 6.4 & COL6A6 & 3.7 & COL10A1 & 3.5 \\
\hline EPYC & 4.3 & TRAM2 & 3.6 & ${ }^{*} A M E L X / / A M E L Y$ & 3.3 \\
\hline \multicolumn{6}{|c|}{ Intercellular and Cell to Matrix Adhesion } \\
\hline MUC15 & 5.7 & CLDN6 & 3.8 & DSG1 & 3.1 \\
\hline PRELP & 4.5 & CD33 & 3.5 & PECAM1 & 3.1 \\
\hline${ }^{*} M C A M$ & 4.0 & SMAGP & 3.5 & EPDR1 & 3.1 \\
\hline${ }^{*}$ GLYCAM1 & 3.9 & ${ }^{*} B O L A-D Q 2$ & 3.3 & CLEC4E & 3.0 \\
\hline SELL & 3.9 & CD96 & 3.2 & & \\
\hline \multicolumn{6}{|c|}{ Ion Transport } \\
\hline TTYH1 & 4.8 & KCNE1 & 3.4 & SLC25A34 & 3.1 \\
\hline FXYD7 & 4.3 & $P 2 R \times 5$ & 3.2 & CACNAID & 3.1 \\
\hline KCNJ15 & 3.5 & TRPM6 & 3.2 & *KCNIP2 & 3.0 \\
\hline \multicolumn{6}{|c|}{ Protein Trafficking } \\
\hline INSIG1 & 3.8 & VPS52 & 3.2 & & \\
\hline \multicolumn{6}{|c|}{ Proteolysis or Inhibition } \\
\hline *PTI & 58.8 & TROAP & 3.5 & $D B C 1$ & 3.2 \\
\hline CPXM2 & 5.2 & MMP7 & 3.4 & TASP1 & 3.2 \\
\hline TFPI & 5.1 & ACE2 & 3.3 & PGA5 & 3.1 \\
\hline PRSS22 & 4.4 & CPB1 & 3.3 & SERPINI2 & 3.1 \\
\hline CUL7 & 4.3 & $S P P L 2 B$ & 3.2 & MMP3 & 3.0 \\
\hline KLK4 & 4.1 & SPAG5 & 3.2 & TRIM8 & 3.0 \\
\hline USP28 & 3.8 & & & & \\
\hline \multicolumn{6}{|c|}{ RNA Processing } \\
\hline DCP1A & 3.6 & U2SURP & 3.0 & & \\
\hline \multicolumn{6}{|c|}{ Transcription Regulation } \\
\hline ZFHX3 & 6.3 & HAND1 & 3.8 & BCORL1 & 3.2 \\
\hline HOXB2 & 4.6 & NFE2L2 & 3.6 & NCOA6 & 3.2 \\
\hline ZNF385A & 4.5 & SP100 & 3.6 & EHMT2 & 3.2 \\
\hline CCNT1 & 4.5 & UHRF1 & 3.5 & $C C 2 D 1 B$ & 3.2 \\
\hline SRCAP & 4.3 & $B C O R$ & 3.5 & IRF2BP1 & 3.2 \\
\hline$\angle D B 1$ & 4.2 & RFX5 & 3.4 & NSD1 & 3.1 \\
\hline POLR3D & 4.0 & NOTCH4 & 3.4 & TFAP2A & 3.1 \\
\hline ELK1 & 4.0 & $A S B 12$ & 3.3 & ZBTB4 & 3.1 \\
\hline VSX1 & 4.0 & NFIA & 3.3 & POUIF1 & 3.1 \\
\hline VGLLI & 3.8 & HOXD9 & 3.2 & ZNF274 & 3.0 \\
\hline \multicolumn{6}{|c|}{ Translation Regulation } \\
\hline YBX2 & 4.9 & EEFSEC & 3.3 & EEFIA1 & 3.1 \\
\hline NARS & 3.3 & & & & \\
\hline \multicolumn{6}{|c|}{ Transport } \\
\hline$A Q P 1$ & 7.0 & $S L C 12 A 8$ & 4.0 & SLCBA1 & 3.4 \\
\hline TRPA 1 & 6.1 & SLC5A9 & 4.0 & EPB42 & 3.4 \\
\hline${ }^{*}$ ATP10A & 6.1 & PDYN & 4.0 & SYNGR3 & 3.3 \\
\hline
\end{tabular}


Table 4 Genes which were down regulated in small atretic follicles with respect to healthy folliclest (Continued)

\begin{tabular}{|c|c|c|c|c|c|}
\hline TNPO1 & 6.0 & $S L C 24 A 1$ & 4.0 & SLC6A9 & 3.2 \\
\hline$A L B$ & 5.7 & $R H B G$ & 4.0 & $A P 4 B 1$ & 3.2 \\
\hline SLC27A3 & 5.5 & ATP13A2 & 3.8 & GOSR1 & 3.2 \\
\hline SLCO2B1 & 5.1 & KIF $20 A$ & 3.6 & ATP4A & 3.2 \\
\hline$A P O B$ & 5.0 & STRA6 & 3.6 & $P L L P$ & 3.2 \\
\hline MAL2 & 4.6 & CLDN16 & 3.5 & FLVCR2 & 3.1 \\
\hline SLC4A2 & 4.5 & SLC7A1 & 3.5 & SLC37A2 & 3.0 \\
\hline ATP2B4 & 4.4 & GC & 3.4 & $S L C 13 A 2$ & 3.0 \\
\hline$A B C D 1$ & 4.2 & ENSA & 3.4 & SLC38A11 & 3.0 \\
\hline SLC16A3 & 4.1 & & & & \\
\hline \multicolumn{6}{|c|}{ Other Enzymes } \\
\hline CYP19A1 & 19.8 & CYP4F2 & 4.2 & PNLIP & 3.4 \\
\hline$A O A H$ & 15.1 & PDE4D & 4.1 & PDE6G & 3.3 \\
\hline *PDK4 & 9.7 & GPT & 4.1 & TRNAUIAP & 3.3 \\
\hline NOS2 & 8.8 & PDP2 & 3.9 & ALDH1L2 & 3.3 \\
\hline ISG20 & 8.4 & $D B T$ & 3.9 & PJA2 & 3.3 \\
\hline ALG3 & 7.8 & $\angle P O$ & 3.9 & WDR46 & 3.3 \\
\hline CHST8 & 7.0 & $A L O X 12 B$ & 3.8 & IPMK & 3.2 \\
\hline HMGCS1 & 6.9 & METTL7B & 3.7 & ST6GAL 1 & 3.2 \\
\hline GCLC & 6.9 & *IGL@ & 3.7 & ALG5 & 3.2 \\
\hline CA14 & 6.8 & ${ }^{*} \mid G H G$ & 3.7 & $C A 5 B$ & 3.2 \\
\hline UGT2B17 & 6.5 & ETNK2 & 3.6 & ACAD10 & 3.2 \\
\hline AKR1C3 & 5.9 & PIPOX & 3.6 & DIO1 & 3.2 \\
\hline GYLTL1B & 5.7 & RNF168 & 3.6 & ACSM1 & 3.1 \\
\hline$S C D$ & 5.6 & LHPP & 3.6 & GSTM4 & 3.1 \\
\hline GPX3 & 5.4 & CYP21A2 & 3.6 & RSAD2 & 3.1 \\
\hline CYP2C19 & 5.2 & NQO1 & 3.6 & ACSM2A & 3.1 \\
\hline GPX2 & 5.0 & METTL21B & 3.5 & SH3GL2 & 3.1 \\
\hline HSD17B1 & 4.8 & GCNT1 & 3.5 & SEPT4 & 3.1 \\
\hline${ }^{*} F H L 3$ & 4.7 & $L P P R 2$ & 3.5 & UBE2C & 3.1 \\
\hline$L P L$ & 4.6 & BCAT1 & 3.5 & RBBP8 & 3.1 \\
\hline PLA2G1B & 4.5 & $B B O X 1$ & 3.5 & B3GNT3 & 3.1 \\
\hline РРРЗСС & 4.5 & PNLIPRP2 & 3.5 & DUSP14 & 3.0 \\
\hline PDE6A & 4.4 & METTLZA & 3.4 & GNA14 & 3.0 \\
\hline FMO2 & 4.4 & P4HA2 & 3.4 & CPS1 & 3.0 \\
\hline TYRP1 & 4.3 & GALNT13 & 3.4 & & \\
\hline$C M B L$ & 4.2 & $D C T$ & 3.4 & & \\
\hline \multicolumn{6}{|c|}{ Other Signalling } \\
\hline $\mathrm{IHH}$ & 7.1 & MAP4K1 & 4.0 & LAT & 3.3 \\
\hline$H L A-A$ & 6.2 & RIC3 & 3.8 & PILRA & 3.3 \\
\hline TBKBP1 & 6.2 & CD84 & 3.8 & GPSM3 & 3.2 \\
\hline *HSPA1A & 5.7 & SHCBP1 & 3.6 & DNAJB1 & 3.1 \\
\hline TESPA 1 & 5.4 & GUCA1A & 3.6 & KIR2DL5A & 3.1 \\
\hline JAK3 & 5.1 & MTUS1 & 3.4 & PEX11B & 3.1 \\
\hline GUCY2F & 4.6 & DOK2 & 3.4 & UPK1A & 3.1 \\
\hline
\end{tabular}


Table 4 Genes which were down regulated in small atretic follicles with respect to healthy folliclest (Continued)

\begin{tabular}{|c|c|c|c|c|c|}
\hline SKAP1 & 4.5 & RPS6KA4 & 3.3 & LY6GGC & 3.1 \\
\hline RASGRP4 & 4.2 & RGS3 & 3.3 & FIGNL1 & 3.0 \\
\hline$B C L 9$ & 4.0 & & & & \\
\hline \multicolumn{6}{|c|}{ Other } \\
\hline CSN2 & 17.7 & EMID1 & 4.3 & GIMAP7 & 3.5 \\
\hline MZB1 & 10.1 & CYLC1 & 4.3 & GUCA2A & 3.4 \\
\hline STAC3 & 6.8 & CCDC159 & 4.3 & PLEKHF2 & 3.4 \\
\hline CCDC3 & 6.3 & C21orf62 & 4.2 & IFI44L & 3.4 \\
\hline C9orf152 & 5.9 & Clorf170 & 4.2 & ODZ3 & 3.4 \\
\hline$A G R 2$ & 5.8 & APOBEC4 & 4.2 & MICA & 3.3 \\
\hline STAC & 5.6 & WWA8 & 4.1 & TMEM139 & 3.3 \\
\hline EFHD1 & 5.5 & PEAR1 & 4.1 & UBN2 & 3.3 \\
\hline MTHFSD & 5.4 & MPDZ & 4.0 & C6orf47 & 3.3 \\
\hline NXPH2 & 5.4 & IFIT2 & 4.0 & $B \operatorname{tn} / 1$ & 3.3 \\
\hline SPEF1 & 5.3 & ELMOD3 & 4.0 & CXorf64 & 3.3 \\
\hline CRISPLD2 & 5.2 & PLEK & 4.0 & DENND2D & 3.3 \\
\hline KLHL29 & 5.2 & SOWAHA & 3.9 & $\mathrm{CHACl}$ & 3.3 \\
\hline MEX3C & 5.0 & GCA & 3.8 & BIRC5 & 3.2 \\
\hline CAMP & 4.7 & LY9 & 3.8 & CAPSL & 3.2 \\
\hline KIAA0101 & 4.6 & CCDC132 & 3.7 & ${ }^{*} \mathrm{RSPH} 10 \mathrm{~B}$ & 3.2 \\
\hline$H R G$ & 4.6 & $C R P$ & 3.6 & ANKRD17 & 3.1 \\
\hline KLHL33 & 4.6 & C16orf53 & 3.6 & ${ }^{*} R N F T 1$ & 3.1 \\
\hline CEP85 & 4.5 & HYOU1 & 3.6 & HYDIN & 3.1 \\
\hline PTGFRN & 4.5 & RASGEF1A & 3.6 & ASPHD1 & 3.1 \\
\hline TMIGD2 & 4.5 & PIP & 3.6 & CCDC97 & 3.0 \\
\hline C6 & 4.4 & OLFML1 & 3.5 & CCDC43 & 3.0 \\
\hline WDR76 & 4.4 & FAM178A & 3.5 & ${ }^{*} P A 1$ & 3.0 \\
\hline MOB3B & 4.4 & TAGLN3 & 3.2 & $M L K L$ & 3.0 \\
\hline RBL2 & 3.8 & TMED6 & 3.2 & WDR87 & 3.0 \\
\hline
\end{tabular}

† Differentially expressed genes $(\geq 3$ fold, $P<0.05$ ) as annotated based on the Entrez Gene database and categorised by function using the Benjamini-Hochberg post-hoc test for multiple corrections following one way ANOVA.

*indicates genes determined from the Partek analysis based on the Affymetrix annotations which were not assigned identities by IPA.

and healthy follicles with a FDR of $P<0.005$, were subjected to pathway analyses in IPA. Of these, 456 were mapped to known identities in the Ingenuity Knowledge database and only 428 were eligible for network generation, due to the presence of replicate probe sets with specificity for the same gene on the chip. This group contained 288 probe sets which were up regulated in atretic with respect to healthy follicles and 140 which were down regulated. The most significantly affected functions associated with this dataset were found to be cell death, organ development, tissue development and embryonic development, which were all predicted to be negatively regulated in atretic follicles (Table 7). Upstream Regulator analysis revealed that the transcription factor genes TP53, FOXO4 and CEBPB are predicted to be activated, whereas those of RXRA, HNF1A and $M Y C$ are inhibited on the basis of known interactions with the genes in our dataset (Table 8). The most significant canonical pathways represented in our analysis are shown in Figure 5. The top ranked canonical pathway (Figure 6), contains signalling molecules from our dataset which are common to various inflammatory/fibrotic pathways such as the transforming growth factor- $\beta$ (TGF $\beta$ ) (Additional file 2: Figure S1) and tumour necrosis factor- $\alpha$ (TNF $\alpha$ ) pathways. The two most significant networks (Figure 7A and 7B) also reflect this pattern of tissue remodelling/fibrosis gene expression. These networks also contain molecules which are present in the canonical pathways of hepatic fibrosis/hepatic stellate cell activation and TGF $\beta$ signalling and are up regulated in our analysis and 


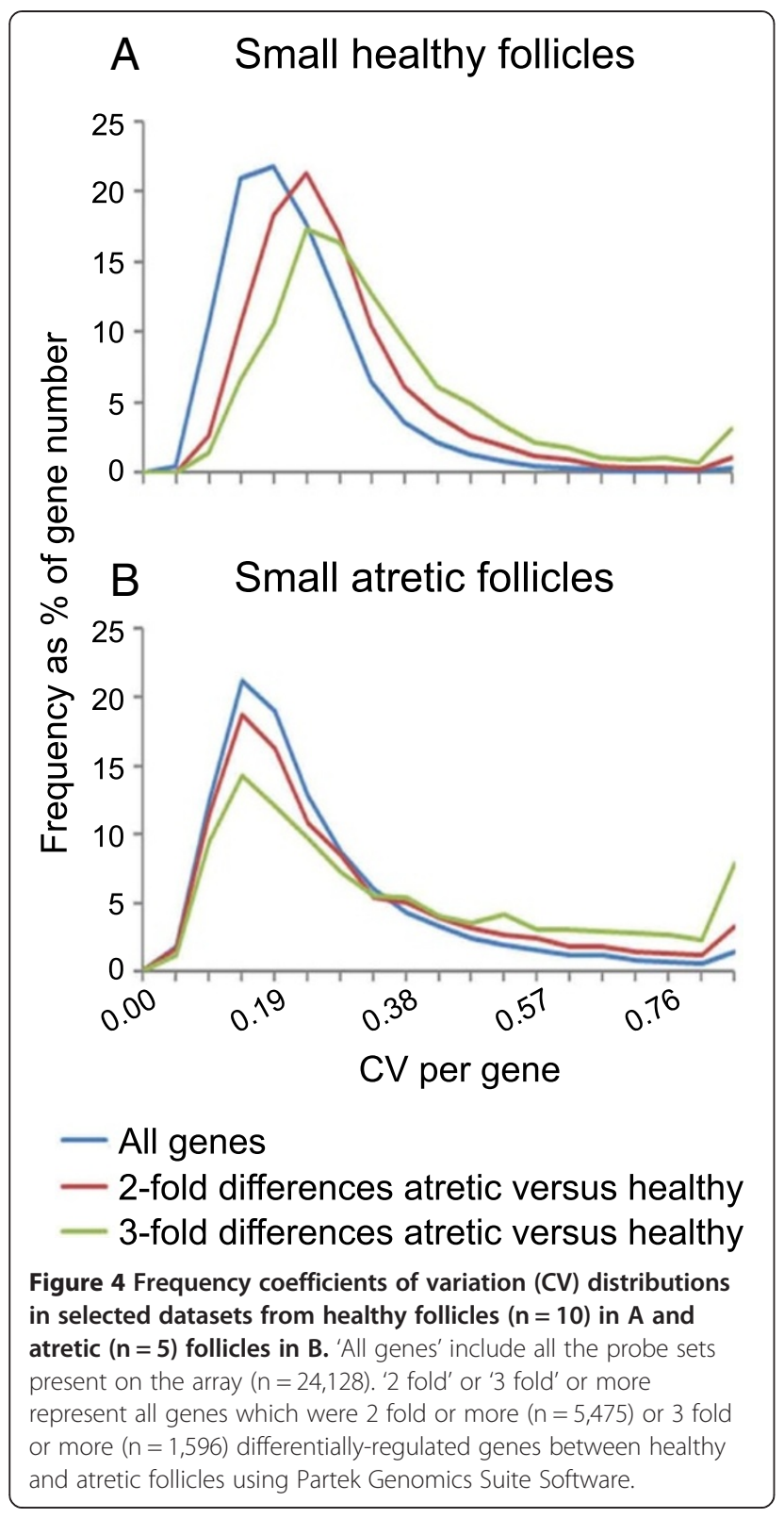

should therefore positively stimulate these networks. These include genes such as THBS2, PLAT, BAMBI, TGFBR2, BMP2, SMAD3, FGFR2, PDGFRA and TIMP1.

$\mathrm{GO}$ enrichment analyses of this dataset determined associations by the categories of biological process, molecular function and cellular component with atresia in granulosa cells from small follicles (Figure 5 and Additional file 3: Table S2). These analyses revealed that blood vessel development and cell adhesion processes were affected through genes such as CTGF and $V E G F A$, and VNN1 and PIK3CA, respectively. The affected products of genes were localised in terms of this analysis to the extracellular matrix and the genes
LAMC2, COL1A2, COL3A1and COL18A1 were found in this group. Other functionally related genes of interest such as IGF2, IGFBP5 and IGFBP6 indicate that insulin growth factor activity appeared to be modulated during the atretic process.

\section{Transcriptional processes of atresia Apoptosis}

Apoptosis is believed to be the major process of cell death occurring in the antral atretic follicle $[7,21]$. There was a significant association in our study between atretic follicles and molecules which are influenced by the p53 transcription factor. p53 is an activator of apoptotic pathways in response to cell stress and functions by regulating cell cycle, DNA repair and metabolic genes [22]. Contrary to expectations, many genes which were up regulated in atretic follicles in this study are actually anti-apoptotic or protective against apoptosis such as CFLAR [23,24], PIK3CA [25,26] and VNN1 [27]. None of the caspases or Fas genes which are known to be involved with apoptotic pathways were found to be differentially expressed to the same extent as those genes mentioned above. Previous studies in cattle and humans have focused on antral follicles of a larger size [11,14,28,29], than those used in this experiment. It is possible that cell death mechanisms that operate in larger follicles are different from those at an earlier stage, where cells are under different hormonal control, LH in addition to FSH, and in the presence of focimatrix [28]. An alternative theory is that only those granulosa cells in the atretic follicle with elevated expression of antiapoptotic genes are capable of surviving longer during the process of apoptosis. This theory would fit with the granulosa stem cell model as proposed previously [30]. This model proposes that different types of granulosa cells within the same follicle are derived from stem cells which grow and divide and eventually differentiate into antral, basal and cumulus granulosa cells in the antral follicle. Hence, at any one time not all granulosa cells would be equal and some could be more susceptible to apoptosis than others, as stem cells in muscle [31], neural [32] and bone marrow [33] are (reviewed in [34]).

\section{Intercellular junctions}

We found increased expression of the claudin tight junction genes CLDN1, CLDN5 and CLDN11 and the Ecadherin gene, $C D H 1$, in atretic follicles. The increase in E-cadherin expression was also verified by immunohistochemistry. Tight junctions act as a critical barrier to the passage of substances between the vasculature and the interior lumen of glands [35] and together with gap junctions help maintain the overall stability of the epithelial layer structure [36]. They are also important for 
Table $\mathbf{5}$ The most variable genes in small healthy follicles mapping to networks and pathways in IPA

\begin{tabular}{|c|c|c|c|c|}
\hline & \multicolumn{2}{|l|}{ Genes mapped from dataset } & & \\
\hline & Symbol & Biological process & & \\
\hline \multirow[t]{10}{*}{ Network $1+($ Score $=42)$} & PLSCR1, PLSCR4, heparanase, CTSL1, ATP2B1 & apoptosis & & \\
\hline & UHRF1 & cell cycle regulation, mitosis & & \\
\hline & TIMP1, & matrix degradation & & \\
\hline & $\underline{E G F R}, \underline{J N B}, \underline{F O S L 2}$ & $\begin{array}{l}\text { differentiation/maturation of } \\
\text { granulosa cell through AP-1 }\end{array}$ & & \\
\hline & CYP19A1, CYP11A1, INHBA, BAMBI & $\begin{array}{l}\text { steroidogenesis, regulation of } \\
\text { gonadotropin secretion/granulosa } \\
\text { cell proliferation }\end{array}$ & & \\
\hline & SOD3 & stress response & & \\
\hline & $A D M$ & regulation of blood supply & & \\
\hline & CLDN11 & maintenance of epithelial integrity & & \\
\hline & VARS & growth metabolism & & \\
\hline & AHNAK & $\begin{array}{l}\text { actin cytoskeleton organisation, } \\
\text { cell polarization }\end{array}$ & & \\
\hline \multirow[t]{4}{*}{ Network 2 †(Score = 42) } & $\begin{array}{l}\text { CCNB1, ESPL1, H1FX, H2AFX, BUB1,NCAPG, NCAPG2, SEPT4, } \\
\text { S100A4, G3BP1 }\end{array}$ & cell cycle regulation, mitosis & & \\
\hline & PSMD4, PSMD13, UBQLN1, PDIA4, HSP70 & protein recycling and folding & & \\
\hline & PEG3 & apoptosis & & \\
\hline & $P R C 1$ & cell migration & & \\
\hline \multirow[t]{2}{*}{ Canonical pathways } & \multirow{2}{*}{\multicolumn{2}{|c|}{ Cell Cycle: G2/M DNA Damage Checkpoint Regulation, Mitotic roles of Polo-Like Kinases }} & \multicolumn{2}{|c|}{$P$ valuett } \\
\hline & & & Fisher's & B-H FDR \\
\hline 1 & CCNB1,CCNB2,CDK1,GADD45A, RPRM, TOP2A, YWHAG & cell cycle regulation, mitosis & $3.2 \times 10^{-4}$ & $5.8 \times 10^{-2}$ \\
\hline 2 & & & $3.9 \times 10^{-4}$ & $5.8 \times 10^{-2}$ \\
\hline \multirow[t]{2}{*}{3} & ATM Signalling & & & \\
\hline & JUN, SMC2, GADD45A, H2AFX, CCNB2, CDK1, CCNB1 & response to DNA damage & $8.2 \times 10^{-4}$ & $8 \times 10^{-2}$ \\
\hline
\end{tabular}

establishing polarity within epithelial cells in general [37]. Properly formed tight junctions have not been observed in the membrana granulosa, though they do exist between Sertoli cells, the analogous cell type in the testis [38]. Gap junctions are present in the granulosa of several species with predominant expression of connexins 43 and 37 (reviewed by [39]). E-cadherin is another protein found at intercellular junctions which is important for cell recognition and adhesion [36], and has been demonstrated in human ovarian follicles [40]. Claudin 1 gene expression has previously been shown to be up regulated during apoptotic insult induced by tamoxifen in some breast tumour cells [41]. Again it is possible that those granulosa cells which have increased expression of these intercellular junction proteins may be able to modulate the effects of apoptotic mechanisms on the cell by stabilising the overall membrana granulosa structure.

\section{Inflammation/TGF $\beta$ signalling/Tissue remodelling}

There have been a number of studies examining TGF $\beta$ signalling molecules in follicle development, though not from the aspect of atresia. This is perhaps surprising given that follicular atresia necessitates a cyclic process of tissue remodelling, and the well-known involvement of the TGF $\beta$ superfamily in tissue repair. In both IPA and GO enrichment analyses, there were a number of genes found to be associated with inflammatory/TGF $\beta$ signalling fibrosis pathways or processes. When we examined the hepatic fibrosis signalling pathway in IPA, with respect to the molecules affected from our dataset, there was increased expression of TGFBR2 and the downstream SMAD genes and subsequently COL1A2 and COL3A1. The TGF $\beta$ receptor has been localised immunohistochemically to the granulosa cells of antral follicles of certain species $[42,43]$, though only in large 
Table 6 GO enrichment analysis of the most variable genes in granulosa cells from small healthy follicles using GOEAST†

\begin{tabular}{|c|c|c|c|c|}
\hline Biological process & Molecular function & Cellular component & Symbol & Entrez gene name \\
\hline \multirow{6}{*}{$\begin{array}{l}\text { Regulation of vascularity } \\
\text { Angiogenesis }(P=0.009)\end{array}$} & & & CYR61 & cysteine-rich angiogenic inducer \\
\hline & & & COL18A1 & collagen 18 \\
\hline & & & THBS1 & thrombospondin 1 \\
\hline & & & CXCR4 & chemokine receptor 4 \\
\hline & & & ANGPT2 & angiopoietin 2 \\
\hline & & & VEGFA & vascular endothelial growth factor A \\
\hline \multirow{13}{*}{$\begin{array}{l}\text { Energy metabolism } \\
\text { Glycogen biosynthetic process } \\
(P=0.044)\end{array}$} & \multirow{13}{*}{$\begin{array}{l}\text { Insulin-like growth factor binding, } \\
\text { two component sensor activity }\end{array}$} & \multirow{13}{*}{ microsome } & ISR2 & insulin receptor 2 \\
\hline & & & EGFR & epidermal growth factor receptor \\
\hline & & & HSP90AA1 & $\begin{array}{l}\text { heat shock protein } 90 \mathrm{kDa} \text { alpha (cytosolic), } \\
\text { class A member } 1\end{array}$ \\
\hline & & & PDK4 & pyruvate dehydrogenase kinase, isozyme 4 \\
\hline & & & IGFBP2 & insulin-like growth factor binding protein 2 \\
\hline & & & CTGF & connective tissue growth factor \\
\hline & & & CYR61 & cysteine-rich angiogenic inducer \\
\hline & & & MGST1 & glutathione transferase 1 \\
\hline & & & CALR & calreticulin \\
\hline & & & PTGES & prostaglandin E synthase \\
\hline & & & PLC4 & phospholipase C, beta 4 \\
\hline & & & OPTN & optineurin \\
\hline & & & ASPSCR1 & $\begin{array}{l}\text { alveolar soft part sarcoma chromosome } \\
\text { region, candidate } 1\end{array}$ \\
\hline \multirow{13}{*}{$\begin{array}{l}\text { Cell Cycle } \\
\text { Mitosis }\left(P=2.3 \times 10^{-5}\right)\end{array}$} & & \multirow{13}{*}{$\begin{array}{l}\text { Condensed chromosome } \\
\text { kinetochore, spindle }\end{array}$} & CCNA2 & cyclin A2 \\
\hline & & & CCNB1 & cyclin B1 \\
\hline & & & CCNB2 & cyclin B2 \\
\hline & & & UBE2 & ubiquitin conjugating enzyme 2 \\
\hline & & & CDK1 & cyclin-dependent kinase 1 \\
\hline & & & NUSAP & nucleolar and spindle associated protein 1 \\
\hline & & & SKA1 & $\begin{array}{l}\text { spindle and kinetochore associated } \\
\text { complex subunit } 1\end{array}$ \\
\hline & & & NUP85 & nucleoporin 85 kDa \\
\hline & & & CENPN & centromere protein $\mathrm{N}$ \\
\hline & & & CENPO & centromere protein $\mathrm{O}$ \\
\hline & & & ZW10 & kinetochore associated homolog \\
\hline & & & BUB1 & $\begin{array}{l}\text { budding inhibited by benzimidazoles } 1 \\
\text { homolog (yeast) }\end{array}$ \\
\hline & & & STK & serine/threonine kinase \\
\hline \multirow{9}{*}{$\begin{array}{l}\text { Extracellular matrix } \\
\text { Extracellular matrix } \\
\text { organisation }(P=0.01)\end{array}$} & \multirow{9}{*}{$\begin{array}{l}\text { Heparin binding, extracellular } \\
\text { matrix binding }\end{array}$} & \multirow[t]{9}{*}{ Basement membrane } & COLIA1 & collagen type I, alpha 1 \\
\hline & & & COL1A2 & collagen type I, alpha 2 \\
\hline & & & COL3A1 & collagen type III, alpha 1 \\
\hline & & & COL4A3 & collagen type IV, alpha 3 \\
\hline & & & COL4A4 & collagen type IV, alpha 4 \\
\hline & & & COL18 & collagen type XVIII \\
\hline & & & $\angle A M B 1$ & laminin, beta 1 \\
\hline & & & VCAN & versican \\
\hline & & & $F M O D$ & fibromodulin \\
\hline
\end{tabular}




\begin{tabular}{|c|c|c|c|}
\hline & & ADAMTS1 & $\begin{array}{l}\text { ADAM metallopeptidase with } \\
\text { thrombospondin type } 1 \text { motif, } 1\end{array}$ \\
\hline & & ADAMTS6 & $\begin{array}{l}\text { ADAM metallopeptidase with } \\
\text { thrombospondin type } 1 \text { motif, } 6\end{array}$ \\
\hline & & MMP2 & matrix metallopeptidase 2 \\
\hline & & TIMP1 & TIMP metallopeptidase inhibitor 1 \\
\hline & & OGN & osteoinductive factor/osteoglycin \\
\hline & & OSF-2 & osteoblast-specific factor 2 \\
\hline & & SPARCL1 & SPARC-like 1 (hevin) \\
\hline & & ASPN & asporin \\
\hline Inflammation & Fibrinogen complex & THBS1 & thrombospondin 1 \\
\hline NOS biosynthesis $(P=0.044)$ & & CALR & calreticulin \\
\hline Antigen processing $(P=0.026)$ & & $B O L A-A$ & $\begin{array}{l}\text { major histocompatibility complex (MHC), } \\
\text { class I, A }\end{array}$ \\
\hline $\begin{array}{l}\text { TGF } \beta \text { receptor signalling } \\
\text { pathway }(P=0.05)\end{array}$ & & $B O L A-N$ & MHC class I antigen \\
\hline \multicolumn{4}{|l|}{ Fibrinolysis $(P=0.09)$} \\
\hline Cell migration & & CXCR4 & chemokine receptor 4 \\
\hline \multirow[t]{8}{*}{ Axon guidance $(P=0.0008)$} & & ABLIM1 & actin binding LIM protein 1 \\
\hline & & COL18 & collagen type XVIII \\
\hline & & EFNA5 & ephrin A5 \\
\hline & & THBS1 & thrombospondin 1 \\
\hline & & EGFR & epidermal growth factor receptor \\
\hline & & TDGF & teratocarcinoma-derived growth factor 1 \\
\hline & & $F 2 R L 1$ & $\begin{array}{l}\text { coagulation factor II (thrombin) } \\
\text { receptor-like } 1\end{array}$ \\
\hline & & INSR & insulin receptor \\
\hline \multirow[t]{3}{*}{ MAPK activity $(P=0.002)$} & & THBS1 & thrombospondin 1 \\
\hline & & TDGF & teratocarcinoma-derived growth factor 1 \\
\hline & & INSR & insulin receptor \\
\hline
\end{tabular}

TThe significance of association for the GO enrichment analysis was determined by the Benjamini-Yekuteli FDR method for multiple comparisons. The variability of expression was determined by a frequency distribution of the coefficients of variation for probe sets across the arrays in the small healthy follicle group. The cut-off chosen was a coefficient of variation of $>46.8 \%$ ( $n=10$ arrays, $n=682$ probe sets).

antral follicles which maybe differentiating as they luteinise. A focus on those genes in our study which are differentially expressed in small follicles, and are expressed at a high level in either the healthy or atretic state, reveals that the inhibin-activin-follistatin axis was most important. INHA and INHBA, which encode activins and inhibin, and FST which produces follistatin, were all down regulated in atretic follicles in our study, which is in agreement with previously published work, as all are required for proper development of the follicle through the antral stage of development $[44,45]$. BAMBI expression in our atretic follicles was increased relative to healthy follicles; the encoded protein is known to bind and inhibit activin and BMP2 (bone morphogenetic protein-2) [46] thus antagonising FSH-induced follicle growth.
Anti-mullerian hormone $(\mathrm{AMH})$ expression was also lower in the atretic follicle. AMH has been shown to delay recruitment of primary follicles to the next stage of growth or possibly atresia [47]. Additionally, AMH has been shown to be up regulated in large dominant bovine follicles versus subdominant and it probably has a survival effect [48]. GDF-9 and BMP-15 are growth factors which have been studied in specific knockouts in mice or mutations in sheep and are known to be important for antral follicle growth (reviewed by [49]). BMP15 was up regulated 3 fold in small healthy follicles in our study, whereas GDF9 was relatively unaffected, the proteins encoded by these genes are secreted specifically by the oocyte $[50,51]$ which makes up a small proportion of the total RNA in our samples, so clearly BMP15 


\begin{tabular}{|c|c|c|c|c|c|}
\hline \multirow[t]{2}{*}{ Category } & \multirow{2}{*}{$\begin{array}{l}\text { Functions } \\
\text { annotation }\end{array}$} & \multicolumn{2}{|c|}{$P$ Value } & \multirow{2}{*}{$\begin{array}{l}\text { Bias- } \\
\text { corrected } \\
\text { z-score }\end{array}$} & \multirow[t]{2}{*}{ Genes } \\
\hline & & Fisher's & $(\mathrm{B}-\mathrm{H}) \mathrm{FDR}$ & & \\
\hline Cancer & $\begin{array}{l}\text { tumorigenesis } \\
\text { of organ }\end{array}$ & 8.31E-04 & $1.57 \mathrm{E}-02$ & -2.907 & $\begin{array}{l}\text { CAV1, CDKN1C, COL18A1, CYP19A1, CYR61, FST, GADD45A, ING4, JUN, } \\
\text { MMP11, NDRG1, SMAD3, STAR, TGFBR2, TIMP1, VEGFA }\end{array}$ \\
\hline Cancer & hyperproliferation & $5.94 \mathrm{E}-05$ & $9.22 \mathrm{E}-03$ & -2.889 & $\begin{array}{l}\text { AXL, BCL6, CAV1, CDKN1C, CEBPD, CYP19A1, FGFR2, FST, GPX3, IGF2R, } \\
\text { ING4, MERTK, MGP, MXI1, NOS2, PLAUR, PLP1, POSTN, SERPINE1, SMAD3, } \\
\text { SPP1, STAR, STAT3, TGFBR2, TIMP1, TOP1, VEGFA }\end{array}$ \\
\hline Cell Death & $\begin{array}{l}\text { cell death of } \\
\text { organ }\end{array}$ & $1.32 \mathrm{E}-10$ & $3.34 \mathrm{E}-08$ & -2.868 & $\begin{array}{l}\text { A2M, AMH, ATF3, AXL, BCL6, BMP2, C8Orf4, CAMP, CAST, CCNT1, CD200, } \\
\text { CDKN1C, CFH, CFLAR, CLIC4, CTGF, CYP19A1, CYP2C9, DCN, DUSP1, EGR1, } \\
\text { GAL, GCLC, GLRX, GNG2, GSN, GTF2F2, ID3, IER3, IGF2, IL18, JUN, KRT8, } \\
\text { LGALS3, LTA, MDK, MERTK, MTPN, MZB1, NOS2, NTRK3, OPRM1, PIK3CA, } \\
\text { PIM1, PLAT, PLAUR, PTPN5, RND3, SERPINA3, SERPINE1, SH3BP5, SMAD3, } \\
\text { SPP1, STAR, STAT3, THBS2, TIMPI, TNFRSF6B, TOP2A, TP53INP1, VEGFA }\end{array}$ \\
\hline $\begin{array}{l}\text { Cell-To-Cell Signalling } \\
\text { and Interaction }\end{array}$ & $\begin{array}{l}\text { activation of } \\
\text { blood cells }\end{array}$ & 5.83E-04 & $1.21 \mathrm{E}-02$ & -2.800 & $\begin{array}{l}\text { AGRN, ANXA1, ANXA2, AXL, C6, CAMP, CD200, CFH, DUSP1, F2RL2, } \\
\text { HDAC7, HLA-A, HRG, IGF2R, IL18, IL18R1, LTA, MERTK, NDRG1, NOS2, } \\
\text { OPRM1, PDGFRA, PELI1, PLAT, PLP1, SMAD3, SPP1, STAT3, TNFRSF12A, } \\
\text { TNFRSFB, VEGFA, WASL }\end{array}$ \\
\hline Cancer & hyperplasia & $2.82 \mathrm{E}-04$ & $7.20 \mathrm{E}-03$ & -2.753 & $\begin{array}{l}\text { AXL, CAV1, CDKN1C, CEBPD, CYP19A1, FGFR2, FST, GPX3, IGF2R, ING4, } \\
\text { MGP, MXI1, NOS2, PLAUR, POSTN, SERPINE1, SPP1, STAR, STAT3, TGFBR2, } \\
\text { TIMP1, TOP1, VEGFA }\end{array}$ \\
\hline Tissue Development & $\begin{array}{l}\text { development } \\
\text { of organ }\end{array}$ & $1.95 \mathrm{E}-09$ & $3.70 \mathrm{E}-07$ & -2.665 & $\begin{array}{l}\text { ADAMTS1, ALB, AMH, ANKRD1, AQP1, ATF3, ATRX, AXL, BCL6, BMP2, } \\
\text { CAMP, CAV1, CDKN1C, CFLAR, CITED2, CLDN1, CLDN11, COLI8A1, } \\
\text { COLIA2, COL3A1, CTGF, CTSH, CYP19A1, CYR61, DCN, EGR1, EPAS1, } \\
\text { ERRFI1, FABP5, FGFR2, FOSL2, FOXP1, FSHB, FST, GAL, HHEX, HRG, ID1, } \\
\text { ID3, IGF2, IGF2R, IGFBP5, IHH, INSIG2, JARID2, JUN, KLF6, KRT18, LAMC2, } \\
\text { LDB1, LGALS3, LTA, MDK, MERTK, MGP, NDP, NOS2, NR2F1, NTRK3, } \\
\text { PDGFRA, PIM1, PLAT, RHO, SERPINE1, SLC4OA1, SLC4A2, SMAD3, SNAI2, } \\
\text { STAT3, TACC2, TDRD7, TGFBR2, THBS2, TIMP1, TNFRSF12A, TYRP1, VCL, } \\
\text { VEGFA, YBX2 }\end{array}$ \\
\hline
\end{tabular}

All predicted to be decreased.

The predicted activation state is inferred from the bias-corrected $z$-score, $(+=$ increased, $-=$ decreased). The bias-corrected $z$-score is computed based on the proportion of target genes present in the dataset which are directionally regulated as expected according to known associations with functions compiled from the literature.

The $P$ value of overlap measures the statistical significance of overlap using Fisher's exact $t$-test or the Benjamini-Hochberg False Discovery Rate for multiple comparisons (B-H FDR), between genes from the dataset and those known to be associated with a function.

expression was activated but the status of GDF9 was not apparent. BMPR2 (bone morphogenetic protein receptor2) encodes a receptor for GDF-9 and BMP-15 and is therefore also critical for follicle expansion. There was a slight increase in BMPR2 in the atretic follicle expression in our study, however, this was not significant. Expression of $B M P 2$ was elevated more than 6 fold in atretic follicles and this member of the BMP family has been implicated in activation of FSH-induced follicle growth and in suppression of luteinisation in human cultured granulosa cells [46]. However, this result was demonstrated in cells obtained from preovulatory follicles and it is unclear whether BMP-2 plays the same role earlier in follicle development.

\section{Angiogenesis}

$V E G F A$ was down regulated in the atretic follicles and $M D K$ (midkine; neurite growth-promoting factor 2) and THBS2 were up regulated in our study. VEGF is a key proangiogenic factor and its expression is known to correlate with the size of healthy antral follicles [52] and is weakly expressed in atretic follicles [53]. Thrombospondins-1 and -2 are anti-angiogenic and are expressed highly during tissue remodelling following injury. Thrombospondin2 in particular appears during the late proliferative phase and is expressed during the remodelling period in conjunction with MMP-2 [54]. Thrombospondin-1 has been shown to promote follicular atresia in rats [55], and together with thrombospondin-2 is expressed inversely with VEGF in a cyclical fashion during folliculogenesis in cows [52]. $M D K$ is expressed in many tissues throughout embryonic development, and it has been shown to antagonise VEGF signalling in vitro and in vivo [56]. Atresia in small antral follicles predictably appears to involve a decrease in blood vessel formation which agrees with previous data.

\section{Insulin metabolism}

We found increased levels of expression of $I G F 2 R$, and the binding protein genes IGFBP5 and IGFBP6 in atretic follicles with respect to healthy follicles. A number of studies have determined the importance of insulin-like growth factor metabolism at antral stages of follicle 
Table 8 Upstream regulators predicted by target gene expression in the atretic versus healthy dataset

\begin{tabular}{|c|c|c|c|c|}
\hline $\begin{array}{l}\text { Upstream } \\
\text { regulator }\end{array}$ & $\begin{array}{l}\text { Predicted } \\
\text { activation state }\end{array}$ & $\begin{array}{l}\text { Bias-corrected } \\
\text { z-Score }\end{array}$ & $\begin{array}{l}P \text { value of } \\
\text { overlap }\end{array}$ & Target molecules in dataset \\
\hline TP53 & activated & 4.272 & $5.78 \mathrm{E}-11$ & $\begin{array}{l}\text { ALB, ANXA1, ANXA2, ARHGEF2, ARPC1B, ATF3, CALD1, CAV1, CFLAR, CLIC4, } \\
\text { CNN1, COL18A1, COL1A2, COL3A1, COL4A1, CTGF, CTSH, CYR61, DKK3, } \\
\text { DUSP1, EGR1, FBLN2, FERMT2, GADD45A, GLRX, GPX3, GSN, HMGCS1, ID1, } \\
\text { ID3, IER3, IFI30, IGF2, IGFBP5, JUN, KRT8, LGALS3, MAP4K1, MMP23B, MPDZ, } \\
\text { NDRG1, NOS2, NR2F1, PCDH7, PDE6A, PGFRA, PHLDA1, PIM1, PLAUR, POSTN, } \\
\text { RAD51AP1, SAT1, SERPINE1, SGK1, SNAI2, SPP1, STAU1, STK17A, TAGLN2, } \\
\text { TGFBR2, THBS2, TOP2A, TP53INP1, VCL, VEGFA }\end{array}$ \\
\hline FOXO4 & activated & 2.203 & $5.41 \mathrm{E}-05$ & BCL6, CTGF, GADD45A, HMGCS1, IER3, SERPINE1, SGK1, VEGFA \\
\hline CEBPB & activated & 2.142 & 1.59E-07 & $\begin{array}{l}\text { ALB, CEBPD, COL1A2, CPT1A, CSN2, CYP19A1, DAB2, DCN, GADD45A, GLIPR2, } \\
\text { ID1, IFIT, M3, MGP, MMP11, NDRG4, NOS2, PDGFRA, PDK4, PLAUR, SAT1, } \\
\text { SERPINE1, SGK1, SPP1, STAR, TMEM176A, TNFAIP6, TOP1 }\end{array}$ \\
\hline RXRA & inhibited & -2.100 & $3.52 \mathrm{E}-04$ & $\begin{array}{l}\text { CEBPD, CPT1A, CYP2C9, FABP5, GCLC, GPT, IER3, LPL, MGP, MMP11, OLR1, } \\
\text { PNMT, SAT1, SLC1OA2, SPP1, STAR, VEGFA }\end{array}$ \\
\hline HNF1A & inhibited & -2.168 & 4.07E-01 & $\begin{array}{l}\text { ALB, BCL6, C1S, CD55, COL3A1, IHH, SERPINE1, SLC1OA2, SLC4OA1, SLC4A2, } \\
\text { UGT2B4 }\end{array}$ \\
\hline MYC & inhibited & -3.197 & 7.80E-07 & $\begin{array}{l}\text { ACTN1, ALB, AQP1, BCL6, CALD1, CAST, CAV1, CD9, CEBPD, CFLAR, CLIC4, } \\
\text { COL1A2, COL3A1, COL4A1, CPT1A, CSTB, DSTN, DUSP1, FABP5, FBLN2, } \\
\text { GADD45A, GCLC, GTF2F2, HLA-A, ID1, ID3, IER3, KLF6, LUM, NDRG1, PLAUR, } \\
\text { PLP1, POLR3D, SGK1, SPP1, TAGLN2, TGFBR2, THBS2, TIMP1, TLN1, TSPO, VEGFA }\end{array}$ \\
\hline MYCN & inhibited & -3.202 & 8.50E-03 & $\begin{array}{l}\text { ARPC1B, CAV1, CCNT1, CITED2, COL18A1, COL4A1, CTGF, DKK3, FGFR2, HLA-A, } \\
\text { SDC2, SERPINE1, TAGLN }\end{array}$ \\
\hline
\end{tabular}

The predicted activation state is inferred from the bias-corrected z-score, (+=activated, - = inhibited). The bias-corrected z-score is computed based on the proportion of target genes present in the dataset which are directionally regulated as expected according to known effects of the regulator on the target compiled from the literature. The $P$ value of overlap measures the statistical significance of overlap using Fisher's exact $t$-test, between genes from the dataset and those known to be acted upon by an upstream regulator.

development [57-60]. IGF-2 acts similarly to IGF-1 to promote proliferation and growth of granulosa cells, but it is specifically bound by IGF-2 receptor which does not signal by the same pathways as the IGF-1 receptor, but rather acts as a clearance mechanism for IGF-2 [61]. The IGF binding proteins bind IGF- 1 and -2 , and thus locally regulate their bioavailability in the follicle [62]. IGFBP-5 has previously been shown to increase in atretic follicles in ruminants [63] perhaps due to increased expression and changing levels of degradative enzymes. Therefore it seems that antral atretic follicles have reduced IGF signalling contributing to lower proliferation and decreased metabolism by granulosa cells as has been previously published.

\section{Extracellular matrix and matrix proteases}

There are several matrix genes which were differentially regulated in our arrays in the atretic follicles including COL1A2, COL3A1, COL4A1, NID2, LAMB1 and LAMC2. Immunostaining confirmed that nidogen-2 protein was increased in atretic follicles. Collagens type I and IV were not detectable in the granulosa cells of small follicles at the small antral stage. Previous immunohistochemical studies $[64,65]$ found that the composition of the extracellular matrix did not change, apart from the presence of laminin $\alpha 2$ in atretic but not healthy follicles, and that laminin $\beta 1$ expression was very weak or nearly absent in small antral atretic follicles [66]. Unfortunately, the laminin $\alpha 2$ gene probe set was not present on the array so this could not be confirmed by the present analysis. It is well known that collagens 1 and 3 are synthesised during the tissue remodelling phase following inflammation [67]. Lee and Dunbar showed an increasing accumulation of laminin $\beta 1 / \gamma 1$ in between granulosa and theca cells in progressively atretic follicles in the pig [68], although a similar study by ourselves in bovine follicles did not indicate differences in laminin $\beta 1$ in the follicular basement membrane and membrana granulosa [66]. Recently, laminin $\gamma 2$ was found to be secreted by cultured epithelial cells in response to wounding and may act as a scaffold for cell migration [69]. The expression of these genes in our current study probably represents a step in the eventual regression of the atretic follicle.

Annexin $A 2$ has been shown to be actively involved in endocytosis and formation of adherens junctions [70]. There is phagocytosis of necrotic cellular debris during atresia and we observed an up regulation of E-cadherin expression in the atretic follicular granulosa cells.

\section{Conclusions}

Small healthy antral follicles, which can undergo a number of growth options, exhibit greater variability in gene expression, particularly in genes associated with cell division and other growth-related functions. It is clear that atresia is associated with transcriptional processes such as the inhibition of blood vessel formation and the 


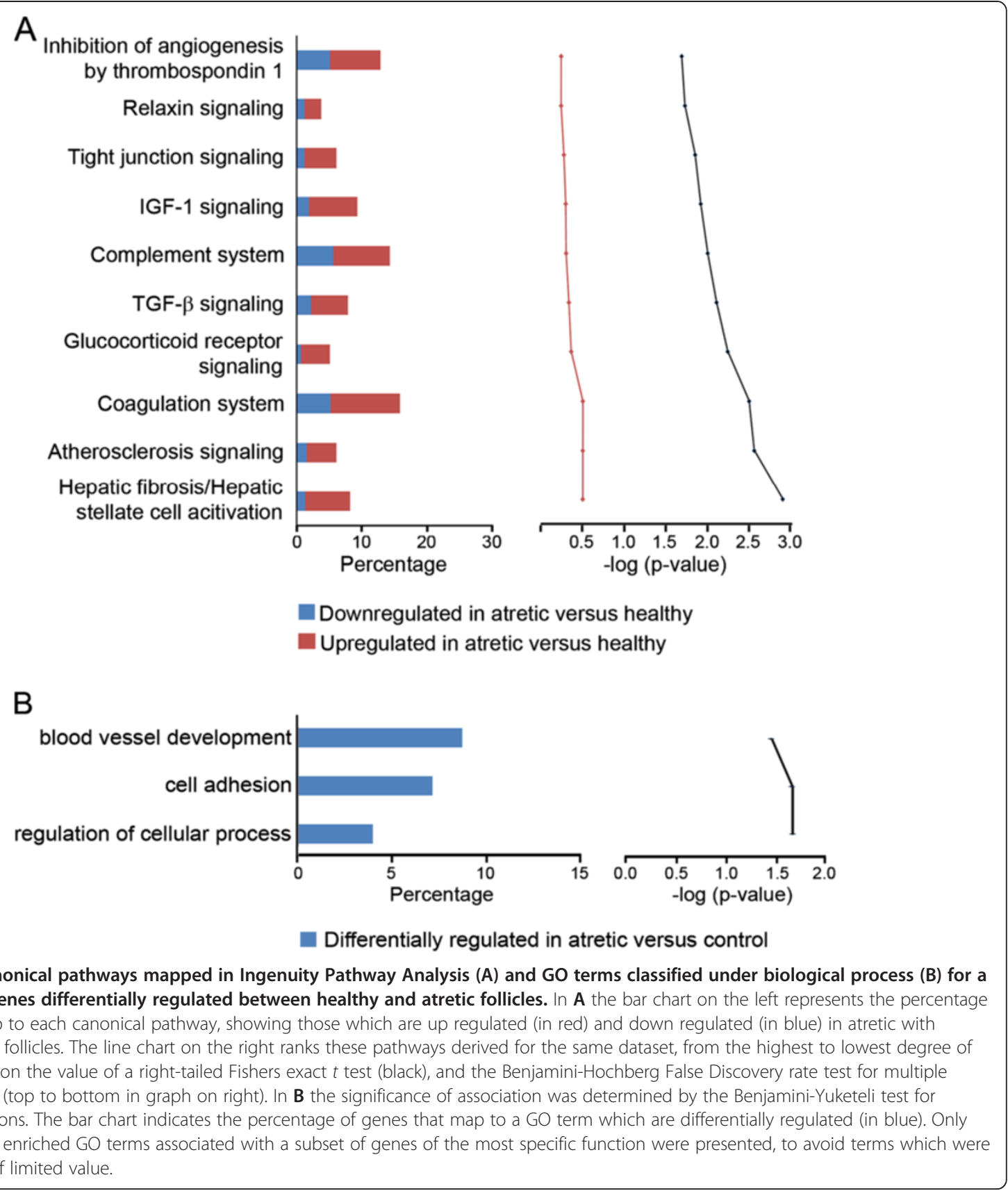

differential expression of matrix genes which may signal the surrounding stromal cells to initiate follicular remodelling. Therefore, atresia not only involves changes in expression of genes associated with cell death but it is clearly also an active process not dissimilar to that of wound healing.

\section{Methods}

\section{Tissues}

Ovaries were collected at a local abattoir in South Australia (from non-pregnant Bos taurus cows, within
20 min of slaughter and transported to the laboratory in Hank's balanced-salt solution with $\mathrm{Mg}^{2+}$ and $\mathrm{Ca}^{2+}$ $\left(\mathrm{HBSS}^{+/+}\right.$; Sigma-Aldrich, Castle Hill, NSW, Australia) on ice. The follicles were dissected from each ovary and the diameter measured. A small piece of the follicle wall, approximately $100 \mathrm{~mm}^{3}$, was removed and fixed in $2.5 \%$ glutaraldehyde in $0.1 \mathrm{M}$ phosphate buffer ( $\mathrm{pH} 7.25)$ for subsequent classification of follicle health status. The granulosa cells were removed from the remainder of the follicles by gentle rubbing with a glass Pasteur pipette, previously modified by heat sealing the tip into a 


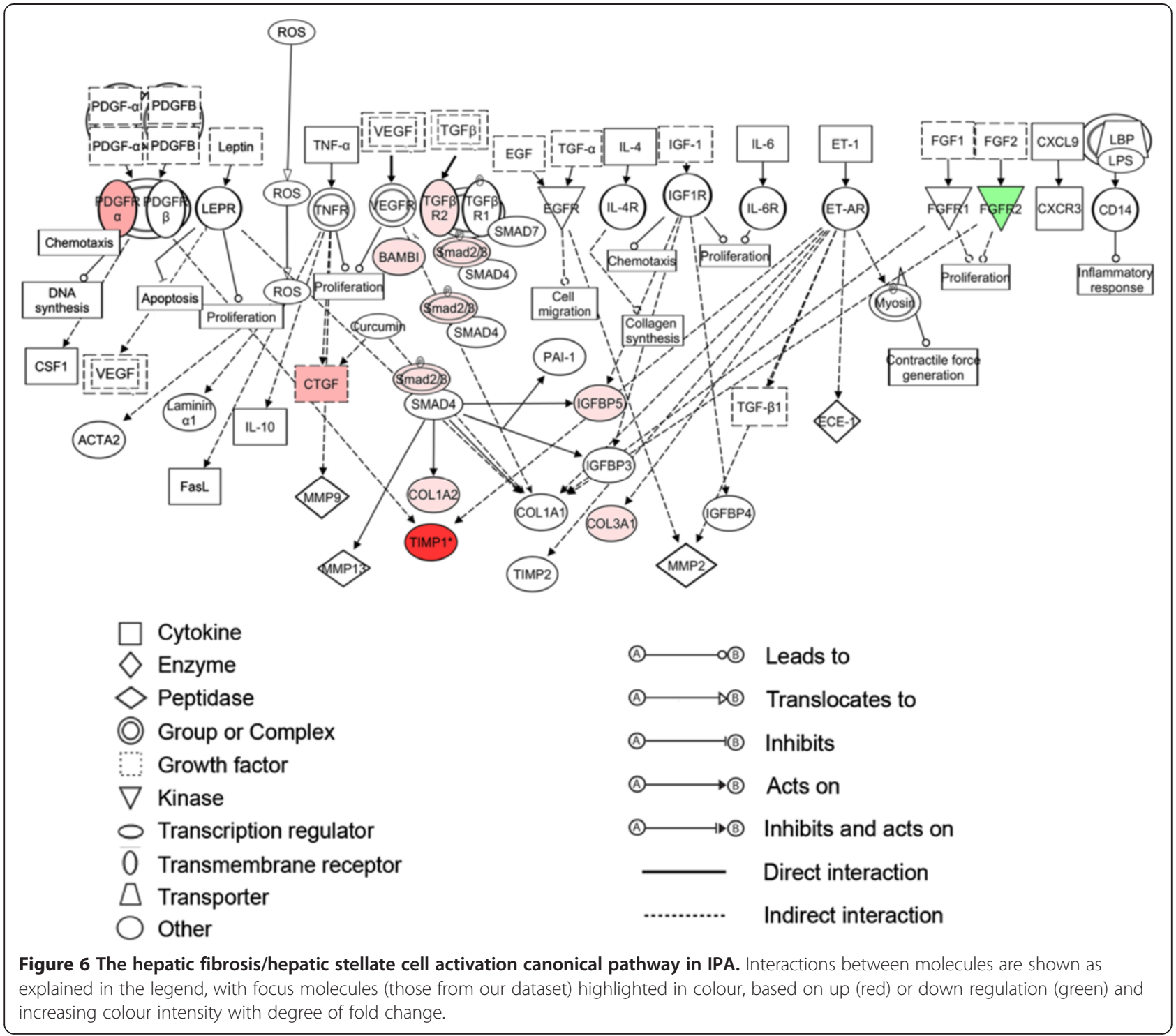

rounded smooth surface. The $\mathrm{HBSS}^{-/-}$containing the granulosa cells was centrifuged at $500 \times g$ for $7 \mathrm{~min}$ at $4^{\circ} \mathrm{C}$, the medium was removed by aspiration and the cells washed twice in phosphate-buffered saline (PBS), pH 7.4. Finally the cells were resuspended in RNAlater (Ambion Life Technologies Australia Pty Ltd., Mulgrave, VIC, Australia), and stored at $-20^{\circ} \mathrm{C}$ for subsequent RNA isolation and microarray analysis. A total of 10 samples of small healthy follicles and 5 small atretic follicles, all $<$ $5 \mathrm{~mm}$ and from different animals, were used in this study. Due to limiting RNA, three of the samples from the small healthy follicles were pools of two follicles each from the same animal, whereas the rest were all individual follicles.

\section{Histological classification of follicles}

Following fixation overnight, the follicle wall portions of each follicle were rinsed several times with $0.1 \mathrm{M}$ PBS,
$\mathrm{pH} 7.25$, post-fixed in $2 \%(\mathrm{v} / \mathrm{v})$ aqueous osmium tetroxide for $1 \mathrm{~h}$ at $4^{\circ} \mathrm{C}$ and embedded in epoxy resin as described previously [71]. For light microscopic examination, $0.5 \mu \mathrm{m}$ thick epoxy sections were cut using a glass knife and a Richert-Jung Ultracut E ultramicrotome (Leica Microsystems Pty Ltd., VIC, Australia), stained with $1 \%(\mathrm{w} / \mathrm{v})$ aqueous methylene blue and examined using an Olympus BX50 microscope (Olympus Australia Pty Ltd., Mt. Waverly, VIC, Australia). Healthy and atretic follicles were identified as described previously $[7,8]$ wherein healthy follicles had no dead or dying granulosa cells and atretic follicles had substantial numbers of dead and dying granulosa cells. This death in atretic follicles was characterized by a loss of layers closest to the antrum and numerous pyknotic nuclei in the remaining antrally-situated layers $[72,73]$. The healthy follicle phenotype was sub-classified into two types, rounded or columnar, based on the shape 


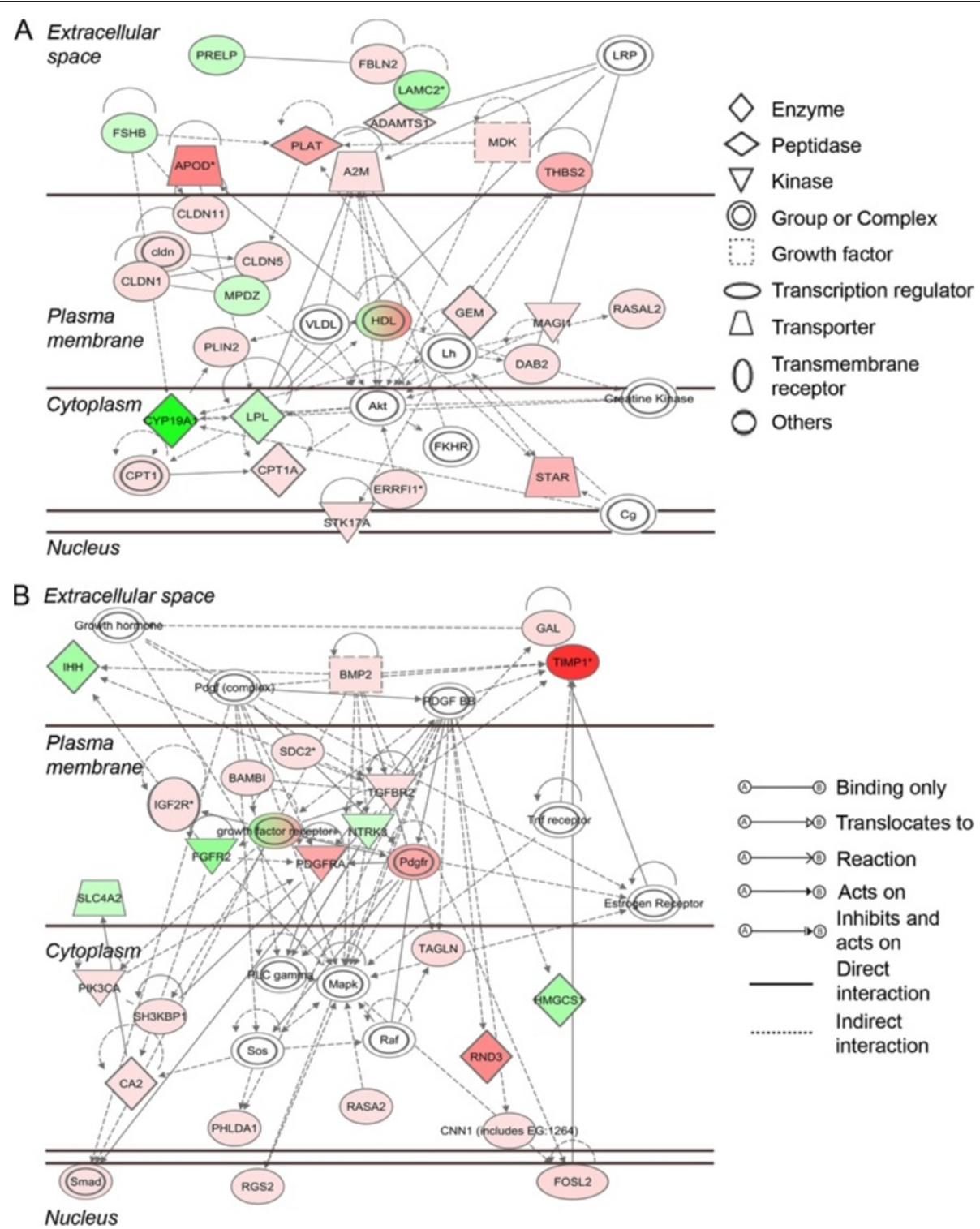

Figure 7 Two statistically significant networks (A and B) produced by mapping differentially expressed genes between healthy and atretic follicles to molecules in the IPA database. The networks are generated in IPA using triangle connectivity based on focus genes (those present in our dataset) and built according to the number of interactions between a single prospective gene and others in the existing network, and the number of interactions the prospective gene has outside this network with other genes as determined by IPA [20]. Interactions between molecules, and the degree and direction of regulation are indicated similarly as in Figure 6 with up (red) or down regulation (green) and increasing colour intensity with degree of fold change.

of the basally-situated granulosa cells $[15,16]$. Additional file 4: Figure $\mathrm{S} 2$ shows examples of each of these follicle types.

\section{RNA isolation}

Total RNA was extracted from the granulosa cells using RNeasy mini RNA extraction kits (Qiagen, Hilden, Germany) and RNAqueous-Micro kit ${ }^{\text {mat }}$ (Ambion $/$ Life Technologies Australia Pty Ltd., Mulgrave, VIC, Australia). The concentration of the RNA was determined by spectrophotometric measurement at $260 \mathrm{~nm}$. For each granulosa cell preparation, $5 \mu \mathrm{g}$ of RNA was treated with DNA-free $\mathrm{e}^{\mathrm{mt}}$ (Ambion Life Technologies). The quality of the RNA was assessed by electrophoresis using an Agilent 2100 Bioanalyser (Agilent Technologies, Santa Clara, CA, USA) and only that with a RNA integrity number exceeding eight was accepted for analysis.

Real time reverse transcription polymerase chain reaction (real time RT-PCR)

Synthesis of cDNA and real time RT-PCR using plasmid standards were performed as previously [74] and briefly 
described below. Total RNA (500 ng) was reverse transcribed with SuperScript ${ }^{\oplus}$ III Transcriptase (Life Technologies) using random hexamer primers (Geneworks, Thebarton, SA, Australia) according to the manufacturer's instructions. Primer Express software (Life Technologies) was used to design primers to the bovine sequences of $18 \mathrm{~S}$ ribosomal RNA and CYP17A1 (Table 9). An ABI Prism 7000 Sequence Detection System (Life Technologies) was used for real time reverse transcription RT-PCR detection with SYBR Green (Eppendorf, Hamburg, Germany) and 10 pmoles of forward and reverse primers in a $20 \mu \mathrm{l}$ reaction. Primer sequences and PCR conditions are shown in Table 9. Plasmid standards were generated by cloning amplified products into pCR2.1-TOPO vector (Life Technologies), then transformed into E.coli strain XL1 Blue (Agilent Technologies) and DNA was extracted and purified. These DNA standards were quantitated by absorbance at $260 \mathrm{~nm}$ and serially diluted over three logs then amplified together with the diluted sample cDNA in the real time reaction to determine quantities of RNA expressed as fg RNA/ng $18 \mathrm{~S}$ ribosomal RNA.

\section{Microarray profiling}

Following confirmation of the quality of RNA and cDNA synthesis, hybridisations to GeneChip Bovine Genome Arrays (Affymetrix, CA, USA) and scanning were performed according to Affymetrix protocols at the Australian Genome Research Facility (AGRF, Walter \& Eliza Hall Institute of Medical Research, Parkville, VIC, Australia) and the Adelaide Microarray Centre (AMC, University of Adelaide, SA, Australia). Between 2 to $5 \mu \mathrm{g}$ from the small healthy follicles and $250 \mathrm{ng}$ of RNA from small atretic follicles was used per probe preparation with the Affymetrix Genechip 3' IVT Express kit. Both types of samples followed a similar labelling and hybridisation procedure as detailed below. First-strand cDNA synthesis was performed using a T7-linked oligo-dT primer, followed by second strand synthesis. In vitro transcription reactions were performed in batches to generate biotinylated cRNA targets, which were subsequently chemically fragmented at $95^{\circ} \mathrm{C}$ for $35 \mathrm{~min}$. Ten micrograms of the fragmented, biotinylated cRNA was hybridised at $45^{\circ} \mathrm{C}$ for $16 \mathrm{~h}$ to Affymetrix GeneChip Bovine Genome Arrays, which contain 24,128 probe sets representing over 23,000 transcripts and variants, including 19,000
UniGene clusters. The arrays were then washed and stained with streptavidin-phycoerythrin (final concentration $10 \mu \mathrm{g} / \mathrm{ml}$ ). Signal amplification was achieved by using a biotinylated anti-streptavidin antibody. The array was then scanned according to the manufacturer's instructions. The scanned images were inspected for the presence of any defect on the array.

\section{Data normalisation and analyses}

To minimize discrepancies due to variables such as sample preparation, hybridisation conditions, staining, or array lot, the raw expression data were normalised using RMA background correction (Robust Multi-array Average [75]) with quantile normalisation, log base 2 transformation and mean probe set summarisation with adjustment for GC content which were performed in Partek Genomics Suite Software version 6.5 (Partek Incorporated, St Louis, MO, USA). All samples sent for analysis passed all quality controls. The 15 arrays were analysed as part of a larger set of CEL files (which additionally included samples of granulosa cell RNA from 4 large follicles as discussed elsewhere [18]) uploaded to the Partek GS software program. Before statistical analysis, the data were first subjected to PCA [76] and hierarchical clustering analysis to compare the gene expression patterns of the arrays in terms of our classification. Hierarchical clustering was performed using the Euclidian algorithm for dissimilarity with average linkage. The expression data were analysed by ANOVA using method of moments estimation [77] with post-hoc stepup FDR test for multiple comparisons. The fold change in expression for each gene was based on the non logtransformed values after correction and normalisation. These differentially expressed genes were further annotated and classified based on the Gene Ontology (GO) consortium annotations from the GO Bos taurus database (2010/02/24) [78] using GOEAST (Gene Ontology Enrichment Analysis Software Toolkit; [79]). Expression data were also exported to Excel and used to generate sizefrequency distributions of the coefficient of variation for each probe set for the two sets of follicles, healthy and atretic. The microarray CEL files, normalised data and experimental information have been deposited in the Gene Expression Omnibus (GEO) database under series record GSE39589.

Pathway analyses of differentially-expressed genes were conducted using IPA software (Redwood City, CA,

Table 9 Primers and conditions used for quantitative RT-PCR

\begin{tabular}{|c|c|c|c|}
\hline Target & Primer sequences, 5'-3' & GenBank accession number & PCR reaction conditions \\
\hline CYP17A1 & $\begin{array}{l}\text { forward accatcagagaagtgctccgaa } \\
\text { reverse ccacaacgtctgtgcctttgt }\end{array}$ & NM_174304 & $\begin{array}{c}2 \min 50^{\circ} \mathrm{C}, 10 \mathrm{~min} 95^{\circ} \mathrm{C}, 40 \times \text { cycles } \\
\text { of } 15 \mathrm{~s} 95^{\circ} \mathrm{C} \text { and } 60 \mathrm{~s} 60^{\circ} \mathrm{C}\end{array}$ \\
\hline $18 \mathrm{~S}$ & $\begin{array}{l}\text { forward agaaacggctaccacatccaa } \\
\text { reverse cctgtattgttatttttcgt }\end{array}$ & DQ2224 & $\begin{array}{c}2 \min 50^{\circ} \mathrm{C}, 10 \mathrm{~min} 95^{\circ} \mathrm{C}, 40 \times \text { cycles } \\
\text { of } 15 \mathrm{~s} 95^{\circ} \mathrm{C} \text { and } 60 \mathrm{~s} 60^{\circ} \mathrm{C}\end{array}$ \\
\hline
\end{tabular}


USA). Network eligible molecules derived from these datasets were overlaid onto a global molecular network developed from information contained in the Ingenuity Knowledge Base. Networks of these molecules were then generated algorithmically based on their connectivity (Ingenuity Systems, 2005). The network score is based on the hypergeometric distribution and is calculated with the right-tailed Fisher's Exact Test. The score is the negative $\log$ of this $P$ value. Canonical pathway analysis identified the pathways from the IPA library of canonical pathways that were most significant to the dataset in terms of the ratio of the number of molecules that mapped to the pathway from the dataset and a righttailed Fisher's exact $t$-test to determine the probability that the molecules mapped to the pathway by chance alone. We also used IPA Upstream regulator analysis to identify upstream transcriptional regulators. Upstream regulators were predicted using a Fisher's exact $t$-test to determine the probability that genes from the dataset correspond with targets which are known to be activated or inhibited by those molecules based on current knowledge in the Ingenuity database.

\section{Immunohistochemistry}

Follicles from bovine ovaries were collected and embedded in O.C.T. compound (ProSciTech, Thuringowa, QLD, Australia) and frozen at $-80^{\circ} \mathrm{C}$. Follicle sections $(7 \mu \mathrm{m})$ were cut using a CM1800 Leica cryostat (Adeal Pty Ltd., Altona North, Vic, Australia), collected on Superfrost ${ }^{\mathrm{tm}}$ glass slides (HD Scientific Supplies, Wetherill Park, Australia), and stored at $-20^{\circ} \mathrm{C}$ until use. Antigen localisation was undertaken on 9 small healthy and 7 small atretic follicles, using an indirect immunofluorescence method as previously described [80]. Frozen follicle sections were dried under vacuum for $5 \mathrm{~min}$, fixed for $5 \mathrm{~min}$ and rinsed three times for $5 \mathrm{~min}$ in hypertonic PBS (10 $\mathrm{mM}$ sodium/potassium phosphate with $0.274 \mathrm{M} \mathrm{NaCl}$, $5 \mathrm{mM} \mathrm{KCl}, \mathrm{pH}$ 7.2) before treatment with blocking solution [10\% normal donkey serum (Sigma-Aldrich) in antibody diluent containing $0.55 \mathrm{M} \mathrm{NaCl}$ and $10 \mathrm{mM}$ sodium phosphate ( $\mathrm{pH}$ 7.1)] for $30 \mathrm{~min}$ at room temperature. The sections were incubated with primary antibodies overnight at room temperature. Additional file 5: Table S3 lists the antibodies used for immunofluorescence and relevant fixation conditions. Sections were also treated with the nuclear stain 4',6'-diamidino-2-phenylindole dihydrochloride (DAPI) solution (Molecular Probes, Eugene, OR, USA) to identify cell nuclei. Coverslips were attached with mounting medium for fluorescence (Dako Corporation, Carpinteria, CA, USA) and photographed with an Olympus BX51TRF microscope with an epifluorescence attachment (Olympus Australia Pty Ltd., Mt Waverley, VIC, Australia) and a Spot RT digital camera (Diagnostic Instruments Inc Pty Ltd., Victora Park, WA, Australia). Negative controls included no primary antisera and non-immune mouse, rabbit or rat serum. No staining of ovarian structures was observed with these controls.

\section{Additional files}

Additional file 1: Table S1. Probe sets which were three fold or more up regulated in granulosa cells of small atretic follicles with respect to small healthy follicles by ANOVA in Partek, with $P<0.05(n=1595)$, in alphabetical order. Probe sets which did not have gene assignations are placed at the end of the list. The $P$ value for multiple corrections was determined by the step-up FDR method.

Additional file 2: Figure S1. The canonical TGF $\beta$ signalling pathway as presented in IPA showing genes which were 4 fold differentially expressed with a FDR $P<0.005$ between atretic and healthy follicles from our dataset. Genes which were up regulated in atretic follicles are indicated in red, and those which were down regulated are green, with the degree of fold difference commensurate with the colour intensity.

Additional file 3: Table S2. Genes which were differentially expressed (4 fold, $P<0.005$ ) in atretic follicles with respect to healthy follicles and associated with significant GO terms after enrichment analysis by GOEAST.

Additional file 4: Figure S2. Histological classification of small antral follicles. Methylene blue stained semi-thin sections of (A) healthy rounded, (B) healthy columnar and (C) atretic small antral follicles. Bar $=50 \mu \mathrm{m}$.

Additional file 5: Table S3. Primary antibodies, secondary antibodies, labelling and fixation conditions used for immunohistochemistry for each antigen. Secondary antibodies used were either biotin-SP-conjugated AffiniPure donkey-anti-mouse IgG (Cat. no. 715-066-151), followed by Cy3-conjugated streptavidin (SA-Cy3, Cat. \# 016-160-084) or fluorescein/ DTAF-conjugated streptavidin (SA-DTAF, Cat. \# 016-010-084), or Cy3conjugated AffiniPure donkey-anti-rabbit lgG (Cat. \# 711-166-152) or antimouse (Cat. \# 715-166-151) or FITC-conjugated AffiniPure donkey-anti-rat lgG (Cat. \# 712-096-153). All secondary antibodies and conjugated streptavidins were purchased from Jackson ImmunoResearch Laboratories Inc. (West Grove, PA, USA) and used at 1:100 dilutions.

\section{Abbreviations}

FDR: Benjamini-Hochberg False Discovery Rate; FSH: Follicle-stimulating hormone; GO: Gene ontology; GOEAST: Gene Ontology Enrichment Analysis Software Toolkit; GEO: Gene Expression Omnibus; HBBS: Hank's balanced-salt solution; IPA: Ingenuity Pathway Analysis; LH: Luteinising hormone; PCA: Principal Component Analysis; RMA: Robust multi-array average; RT-PCR: Reverse transcription polymerase chain reaction; TGF $\beta$ : Transforming growth factor beta; TNFa: Tumour necrosis factor alpha.

\section{Competing interests}

No conflicts of interest, financial or otherwise, are declared by the authors.

\section{Authors' contributions}

Conceived and designed the experiments: HFI-R and RJR. Performed the experiments: $\mathrm{NH}, \mathrm{KH}$ HFI-R, MLH and SEM. Analysed the data: $\mathrm{NH}, \mathrm{KH}$ and RJR. Contributed reagents/materials/analysis tools: $\mathrm{NH}, \mathrm{KH}$ and RJR. Wrote the paper: $\mathrm{NH}, \mathrm{KH}, \mathrm{HFI}-\mathrm{R}$ and RJR. All authors read and approved the final manuscript.

\section{Acknowledgements}

We thank Drs Richard D'Andrea, Thomas Ohnesorg, Andrew Sakko, Yi Peng, Anand Venkatraman, David Adelson, Cristin Print, William Rainey and Angela Chang and for their discussions and earlier contributions to this study and T\&R Pastoral for donation of ovaries. This work was supported by the National Health and Medical Research Council of Australia, the Australian Research Council and the University of Adelaide.

\section{Author details}

${ }^{1}$ Research Centre for Reproductive Health, Discipline of Obstetrics and Gynaecology, School of Paediatrics and Reproductive Health, Robinson 
Institute, University of Adelaide, Adelaide 5005SA, Australia. ${ }^{2}$ Current Address: School of Medical Science, Griffith University, Gold Coast 4222 QLD, Australia.

Received: 30 June 2013 Accepted: 2 January 2014

Published: 18 January 2014

\section{References}

1. van Wezel IL, Rodgers RJ: Morphological characterization of bovine primordial follicles and their environment in vivo. Biol Reprod 1996, 55(5):1003-1011.

2. Lussier JG, Matton P, Dufour JJ: Growth rates of follicles in the ovary of the cow. J Reprod Fertil 1987, 81(2):301-307.

3. Mihm M, Bleach EC: Endocrine regulation of ovarian antral follicle development in cattle. Anim Reprod Sci 2003, 78(3-4):217-237.

4. Milvae RA, Hinckley ST, Carlson JC: Luteotropic and luteolytic mechanisms in the bovine corpus luteum. Theriogenology 1996, 45(7):1327-1349.

5. Faddy MJ, Gosden RG, Gougeon A, Richardson SJ, Nelson JF: Accelerated disappearance of ovarian follicles in mid-life: implications for forecasting menopause. Hum Reprod 1992, 7(10):1342-1346.

6. Rothchild I: The yolkless egg and the evolution of eutherian viviparity. Biol Reprod 2003, 68(2):337-357.

7. Irving-Rodgers HF, van Wezel IL, Mussard ML, Kinder JE, Rodgers RJ: Atresia revisited: two basic patterns of atresia of bovine antral follicles. Reproduction 2001, 122(5):761-775.

8. Rodgers RJ, Irving-Rodgers HF: Morphological classification of bovine ovarian follicles. Reproduction 2010, 139(2):309-318.

9. Schultz GS, Wysocki A: Interactions between extracellular matrix and growth factors in wound healing. Wound Repair Regen 2009, 17(2):153-162

10. Martin $\mathrm{P}$ : Wound healing-aiming for perfect skin regeneration. Science 1997, 276(5309):75-81.

11. Evans AC, Ireland JL, Winn ME, Lonergan P, Smith GW, Coussens PM, Ireland $\mathrm{JJ}$ : Identification of genes involved in apoptosis and dominant follicle development during follicular waves in cattle. Biol Reprod 2004, 70(5):1475-1484.

12. Mihm M, Baker PJ, Fleming LM, Monteiro AM, O'Shaughnessy PJ: Differentiation of the bovine dominant follicle from the cohort upregulates mRNA expression for new tissue development genes. Reproduction 2008, 135(2):253-265.

13. Skinner MK, Schmidt M, Savenkova MI, Sadler-Riggleman I, Nilsson EE: Regulation of granulosa and theca cell transcriptomes during ovarian antral follicle development. Mol Reprod Dev 2008, 75(9):1457-1472.

14. Liu Z, Youngquist RS, Garverick HA, Antoniou E: Molecular mechanisms regulating bovine ovarian follicular selection. Mol Reprod Dev 2009, 76(4):351-366.

15. Irving-Rodgers HF, Rodgers RJ: Ultrastructure of the basal lamina of bovine ovarian follicles and its relationship to the membrana granulosa. J Reprod Fertil 2000, 118(2):221-228.

16. Irving-Rodgers HF, Morris S, Collett RA, Peura TT, Davy M, Thompson JG, Mason HD, Rodgers RJ: Phenotypes of the ovarian follicular basal lamina predict developmental competence of oocytes. Hum Reprod 2009, 24(4):936-944

17. Rodgers RJ, Rodgers HF, Hall PF, Waterman MR, Simpson ER: Immunolocalization of cholesterol side-chain-cleavage cytochrome P-450 and 17 alpha-hydroxylase cytochrome P-450 in bovine ovarian follicles. J Reprod Fertil 1986, 78(2):627-638.

18. Hatzirodos N, Irving-Rodgers HF, Hummitzsch K, Harland ML, Morris SE, Rodgers RJ: Transcriptome profiling of granulosa cells of bovine ovarian follicles during growth from small to large antral sizes. BMC Genomics 2014, 15:24-53.

19. Mar JC, Matigian NA, Mackay-Sim A, Mellick GD, Sue CM, Silburn PA, McGrath JJ, Quackenbush J, Wells CA: Variance of gene expression identifies altered network constraints in neurological disease. PLOS Genet 2011, 7(8):e1002207.

20. IPA Network Generation Algorithm, White paper. In Ingenuity Systems.; 2005.

21. Yang MY, Rajamahendran R: Involvement of apoptosis in the atresia of nonovulatory dominant follicle during the bovine estrous cycle. Biol Reprod 2000, 63(5):1313-1321.

22. Pei D, Zhang $Y$, Zheng J: Regulation of p53: a collaboration between Mdm2 and Mdmx. Oncotarget 2012, 3(3):228-235.
23. Xiao CW, Asselin E, Tsang BK: Nuclear factor kappaB-mediated induction of Flice-like inhibitory protein prevents tumor necrosis factor alpha-induced apoptosis in rat granulosa cells. Biol Reprod 2002, 67(2):436-441.

24. Matsuda F, Inoue N, Goto Y, Maeda A, Cheng Y, Sakamaki K, Manabe N: cFLIP regulates death receptor-mediated apoptosis in an ovarian granulosa cell line by inhibiting procaspase-8 cleavage. J Reprod Dev 2008, 54(5):314-320.

25. Sanchez F, Romero S, Smitz J: Oocyte and cumulus cell transcripts from cultured mouse follicles are induced to deviate from normal in vivo conditions by combinations of insulin, follicle-stimulating hormone, and human chorionic gonadotropin. Biol Reprod 2011, 85(3):565-574.

26. Kennedy SG, Wagner AJ, Conzen SD, Jordan J, Bellacosa A, Tsichlis PN, Hay $\mathrm{N}$ : The PI 3-kinase/Akt signaling pathway delivers an anti-apoptotic signal. Genes Dev 1997, 11(6):701-713.

27. Berruyer C, Martin FM, Castellano R, Macone A, Malergue F, Garrido-Urbani S, Millet V, Imbert J, Dupre S, Pitari G, et al: Vanin-1-/- mice exhibit a glutathione-mediated tissue resistance to oxidative stress. Mol Cell Biol 2004, 24(16):7214-7224.

28. Irving-Rodgers HF, Harland ML, Rodgers RJ: A novel basal lamina matrix of the stratified epithelium of the ovarian follicle. Matrix Biol 2004, 23(4):207-217

29. Glamoclija V, Vilovic K, Saraga-Babic M, Baranovic A, Sapunar D: Apoptosis and active caspase-3 expression in human granulosa cells. Fertil Steril 2005, 83(2):426-431.

30. Rodgers RJ, Lavranos TC, van Wezel IL, Irving-Rodgers HF: Development of the ovarian follicular epithelium. Mol Cell Endocrinol 1999, 151(1-2):171-179.

31. Caiozzo VJ, Giedzinski E, Baker M, Suarez T, Izadi A, Lan M, Cho-Lim J, Tseng $\mathrm{BP}$, Limoli CL: The radiosensitivity of satellite cells: cell cycle regulation, apoptosis and oxidative stress. Radiat Res 2010, 174(5):582-589.

32. Acharya MM, Lan ML, Kan VH, Patel NH, Giedzinski E, Tseng BP, Limoli CL: Consequences of ionizing radiation-induced damage in human neural stem cells. Free Radic Biol Med 2010, 49(12):1846-1855.

33. Mussano F, Lee KJ, Zuk P, Tran L, Cacalano NA, Jewett A, Carossa S, Nishimura I: Differential effect of ionizing radiation exposure on multipotent and differentiation-restricted bone marrow mesenchymal stem cells. J Cell Biochem 2010, 111(2):322-332.

34. Lane AA, Scadden DT: Stem cells and DNA damage: persist or perish? Cell 2010, 142(3):360-362.

35. Anderson JM, Van Itallie CM, Fanning AS: Setting up a selective barrier at the apical junction complex. Curr Opin Cell Biol 2004, 16(2):140-145.

36. Gumbiner BM: Regulation of cadherin-mediated adhesion in morphogenesis. Nat Rev Mol Cell Biol 2005, 6(8):622-634.

37. Nelson WJ: Adaptation of core mechanisms to generate cell polarity. Nature 2003, 422(6933):766-774.

38. Vitale R, Fawcett DW, Dym M: The normal development of the bloodtestis barrier and the effects of clomiphene and estrogen treatment. Anat Rec 1973, 176(3):331-344.

39. Gershon E, Plaks V, Dekel N: Gap junctions in the ovary: expression, localization and function. Mol Cell Endocrinol 2008, 282(1-2):18-25.

40. Ohishi Y, Oda Y, Kurihara S, Kaku T, Kobayashi H, Wake N, Tsuneyoshi M: Nuclear localization of E-cadherin but not beta-catenin in human ovarian granulosa cell tumours and normal ovarian follicles and ovarian stroma. Histopathology 2011, 58(3):423-432.

41. Akasaka H, Sato F, Morohashi S, Wu Y, Liu Y, Kondo J, Odagiri H, Hakamada K, Kijima H: Anti-apoptotic effect of claudin-1 in tamoxifen-treated human breast cancer MCF-7 cells. BMC Cancer 2010, 10:548.

42. Bristol SK, Woodruff TK: Follicle-restricted compartmentalization of transforming growth factor beta superfamily ligands in the feline ovary. Biol Reprod 2004, 70(3):846-859.

43. Wehrenberg U, Giebel J, Rune GM: Possible involvement of transforming growth factor-beta 1 and transforming growth factor-beta receptor type II during luteinization in the marmoset ovary. Tissue Cell 1998, 30(3):360-367.

44. Knight PG, Glister C: TGF-beta superfamily members and ovarian follicle development. Reproduction 2006, 132(2):191-206.

45. Binelli M, Murphy BD: Coordinated regulation of follicle development by germ and somatic cells. Reprod Fertil Dev 2010, 22(1):1-12.

46. Shi J, Yoshino O, Osuga Y, Koga K, Hirota Y, Nose E, Nishii O, Yano T, Taketani Y: Bone morphogenetic protein-2 (BMP-2) increases gene expression of $\mathrm{FSH}$ receptor and aromatase and decreases gene expression 
of LH receptor and StAR in human granulosa cells. Am J Reprod Immunol 2011, 65(4):421-427.

47. Gruijters MJ, Visser JA, Durlinger AL, Themmen AP: Anti-Mullerian hormone and its role in ovarian function. Mol Cell Endocrinol 2003, 211(1-2):85-90.

48. Hayashi KG, Ushizawa K, Hosoe M, Takahashi T: Differential genome-wide gene expression profiling of bovine largest and second-largest follicles: identification of genes associated with growth of dominant follicles. Reprod Biol Endocrinol 2010, 8:11.

49. Otsuka F, McTavish KJ, Shimasaki S: Integral role of GDF-9 and BMP-15 in ovarian function. Mol Reprod Dev 2011, 78(1):9-21.

50. Dong J, Albertini DF, Nishimori K, Kumar TR, Lu N, Matzuk MM: Growth differentiation factor-9 is required during early ovarian folliculogenesis. Nature 1996, 383(6600):531-535.

51. Dube JL, Wang P, Elvin J, Lyons KM, Celeste AJ, Matzuk MM: The bone morphogenetic protein 15 gene is $\mathrm{X}$-linked and expressed in oocytes. Mol Endocrinol 1998, 12(12):1809-1817.

52. Greenaway J, Gentry PA, Feige JJ, LaMarre J, Petrik JJ: Thrombospondin and vascular endothelial growth factor are cyclically expressed in an inverse pattern during bovine ovarian follicle development. Biol Reprod 2005, 72(5):1071-1078.

53. Ferrara N, Frantz G, LeCouter J, Dillard-Telm L, Pham T, Draksharapu A, Giordano T, Peale F: Differential expression of the angiogenic factor genes vascular endothelial growth factor (VEGF) and endocrine glandderived VEGF in normal and polycystic human ovaries. Am J Pathol 2003, 162(6):1881-1893.

54. Bornstein P, Agah A, Kyriakides TR: The role of thrombospondins 1 and 2 in the regulation of cell-matrix interactions, collagen fibril formation, and the response to injury. Int J Biochem Cell Biol 2004, 36(6):1115-1125.

55. Garside SA, Harlow CR, Hillier SG, Fraser HM, Thomas FH: Thrombospondin1 inhibits angiogenesis and promotes follicular atresia in a novel in vitro angiogenesis assay. Endocrinology 2010, 151(3):1280-1289.

56. van der Horst EH, Frank BT, Chinn L, Coxon A, Li S, Polesso F, Slavin A, Ruefli-Brasse A, Wesche $\mathrm{H}$ : The growth factor Midkine antagonizes VEGF signaling in vitro and in vivo. Neoplasia 2008, 10(4):340-347.

57. Monniaux D, Pisselet C: Control of proliferation and differentiation of ovine granulosa cells by insulin-like growth factor-I and folliclestimulating hormone in vitro. Biol Reprod 1992, 46(1):109-119.

58. Baker J, Hardy MP, Zhou J, Bondy C, Lupu F, Bellve AR, Efstratiadis A: Effects of an Igf1 gene null mutation on mouse reproduction. Mol Endocrinol 1996, 10(7):903-918.

59. Walters KA, Binnie JP, Campbell BK, Armstrong DG, Telfer EE: The effects of IGF-I on bovine follicle development and IGFBP-2 expression are dose and stage dependent. Reproduction 2006, 131(3):515-523.

60. Ginther OJ, Gastal EL, Gastal MO, Beg MA: Intrafollicular effect of IGF1 on development of follicle dominance in mares. Anim Reprod Sci 2008, 105(3-4):417-423.

61. O'Dell SD, Day IN: Insulin-like growth factor II (IGF-II). Int J Biochem Cell Biol 1998, 30(7):767-771.

62. Silva JR, Figueiredo $J R$, van den Hurk R: Involvement of growth hormone (GH) and insulin-like growth factor (IGF) system in ovarian folliculogenesis. Theriogenology 2009, 71(8):1193-1208.

63. Monget $P$, Fabre $S$, Mulsant $P$, Lecerf F, Elsen JM, Mazerbourg S, Pisselet $C$, Monniaux D: Regulation of ovarian folliculogenesis by IGF and BMP system in domestic animals. Domest Anim Endocrinol 2002, 23(1-2):139-154.

64. Rodgers RJ, Irving-Rodgers HF: Extracellular matrix of the bovine ovarian membrana granulosa. Mol Cell Endocrinol 2002, 191(1):57-64.

65. Rodgers RJ, Irving-Rodgers HF, Russell DL: Extracellular matrix of the developing ovarian follicle. Reproduction 2003, 126(4):415-424.

66. van Wezel IL, Rodgers HF, Rodgers RJ: Differential localization of laminin chains in bovine follicles. J Reprod Fertil 1998, 112(2):267-278.

67. Barnes MJ, Morton LF, Bennett RC, Bailey AJ, Sims TJ: Presence of type III collagen in guinea-pig dermal scar. Biochem J 1976, 157(1):263-266.

68. Lee VH, Britt JH, Dunbar BS: Localization of laminin proteins during early follicular development in pig and rabbit ovaries. J Reprod Fertil 1996, 108(1):115-122.

69. Kinumatsu T, Hashimoto S, Muramatsu T, Sasaki H, Jung HS, Yamada S, Shimono M: Involvement of laminin and integrins in adhesion and migration of junctional epithelium cells. J Periodontal Res 2009, 44(1):13-20.

70. Grieve AG, Moss SE, Hayes MJ: Annexin A2 at the interface of actin and membrane dynamics: a focus on its roles in endocytosis and cell polarization. Int J Cell Biol 2012, 2012:852430.
71. Irving-Rodgers HF, Catanzariti KD, Aspden WJ, D'Occhio MJ, Rodgers RJ: Remodeling of extracellular matrix at ovulation of the bovine ovarian follicle. Molec Reprod Devel 2006, 73(10):1292-1302.

72. Irving-Rodgers HF, Krupa M, Rodgers RJ: Cholesterol side-chain cleavage cytochrome P450 and 3beta-hydroxysteroid dehydrogenase expression and the concentrations of steroid hormones in the follicular fluids of different phenotypes of healthy and atretic bovine ovarian follicles. Biol Reprod 2003, 69(6):2022-2028.

73. Clark LJ, Irving-Rodgers HF, Dharmarajan AM, Rodgers RJ: Theca interna: the other side of bovine follicular atresia. Biol Reprod 2004, 71(4):1071-1078.

74. Prodoehl MJ, Irving-Rodgers HF, Bonner WM, Sullivan TM, Micke GC, Gibson MA, Perry VE, Rodgers RJ: Fibrillins and latent TGFbeta binding proteins in bovine ovaries of offspring following high or low protein diets during pregnancy of dams. Mol Cell Endocrinol 2009, 307(1-2):133-141.

75. Irizarry RA, Hobbs B, Collin F, Beazer-Barclay YD, Antonellis KJ, Scherf U, Speed TP: Exploration, normalization, and summaries of high density oligonucleotide array probe level data. Biostatistics 2003, 4(2):249-264.

76. Hotelling $\mathrm{H}$ : Analysis of a complex of statistical variables into principal components. J Educ Psychol 1933, 24:417-441.

77. Eisenhart C: The assumptions underlying the analysis of variance. Biometrics 1947, 3(1):1-21.

78. Ashburner M, Ball CA, Blake JA, Botstein D, Butler H, Cherry JM, Davis AP, Dolinski K, Dwight SS, Eppig JT, et al: Gene ontology: tool for the unification of biology. The Gene Ontology Consortium. Nat Genet 2000, 25(1):25-29.

79. Zheng Q, Wang XJ: GOEAST: a web-based software toolkit for Gene Ontology enrichment analysis. Nucleic Acids Res 2008, 36(Web Server issue):W358-W363.

80. Irving-Rodgers HF, Bathgate RA, Ivell R, Domagalski R, Rodgers RJ: Dynamic changes in the expression of relaxin-like factor (INSL3), cholesterol sidechain cleavage cytochrome p450, and 3beta-hydroxysteroid dehydrogenase in bovine ovarian follicles during growth and atresia. Biol Reprod 2002, 66(4):934-943.

\section{doi:10.1186/1471-2164-15-40}

Cite this article as: Hatzirodos et al:: Transcriptome profiling of granulosa cells from bovine ovarian follicles during atresia. BMC Genomics 2014 15:40.

\section{Submit your next manuscript to BioMed Central and take full advantage of:}

- Convenient online submission

- Thorough peer review

- No space constraints or color figure charges

- Immediate publication on acceptance

- Inclusion in PubMed, CAS, Scopus and Google Scholar

- Research which is freely available for redistribution

Submit your manuscript at www.biomedcentral.com/submit
C) Biomed Central 